\title{
Final report on studies of nutrient \\ cycling on white and black water areas in Amazonia
}

\author{
N. Stark (") \\ C. Holley ( $\left.{ }^{*}\right)$
}

\begin{abstract}
Studies were conducted near Manaus, Brazil in cooperation with INPA to try to establish how nutrient cycling influences the formation of black water and white water. The studies measured the rate of decay of Caryocar villosum leaves on spodosol and oxisol terrestrial and aquatic sites when the leaves were untreated, and treated with a bacteriostat, or insecticide or fungicide. It also measured litter, animal populations, and the elemental content of ten biologically important elements in soils and decomposing litter. Results show corsiderable differences in the rates of decay and the agents and end products of decay which indicate that black water and white water formation are closely tied to the rate and type of decay and to basic soil types and their associated vegetation, except for the sediments in white water.
\end{abstract}

\section{INTRODUCTION}

It was observed long ago that the areas of Amazonia which generate black water rivers have white sands which have undergone podzolization, while those which produce white water rivers have oxisols from which silica has been leached. The two processes, podzolization and laterization (producing oxisols in the new terminology) differ primarily in the $\mathrm{pH}$ of the leaching solution which reaches the soil, and the oxidation conditions. Spodosols are thought to be produced when the leachate from the litter into the soil is acid, thus making iron and aluminum readily soluble and hence leachable. Oxisols are produced when the leachate passing from the litter into the soil is more nearly alkaline so that silica is solubilized and leached to deeper horizons. The extensive differences between black water and white water (Klinge, 1967; Williams et al., 1972) are thought to arise from differences originating with these two soil forming processes, and some differences of parent material.

The suspended material characteristic of white water is carried by these streams because of the nature of the clays that form on the oxisols which generate white water. However, clays from black water areas from the spodosols will turn the water milky white when these clays are soaked for a long period of time. White water per se, often has black water in it and swampy areas on oxisols may give rise to black water. Also, the leaves of many types of tropical and temperate vegetation will produce black water of one type in acid conditions and black water of another type in alkaline conditions.

Since the precipitation which falls over forests on oxisols and spodosols is about the same in $\mathrm{pH}(4-5)$, the differences in the $\mathrm{pH}$ of the leaching solution must arise as a result of the chemical changes occurring on the leaf and bark surfaces during throughfall and stemflow, and within the litter itself during decomposition. The differences between the two major soil groups (oxisol and spodosol) in the tropics, and their resultant water chemistry have never been closely tied to the chemical processes which dominate litter decomposition. This study attempted to determine whether black water is actually generated on land or under water, and what the major decomposer groups were on spodosols and cxisols as well as in black and white waters in Amazonia.

(") - School of Forestry, University of Montana. Missoula, Montana. 
Many studies have dealt with the mysteries of black and white water (Brinkman, 1970 and personal communication; Fittkau, 1967; Sioli et al., 1969; Schmidt, 1970). In the last ten years, many studies of water quality have been conducted to try to describe the water of this huge network of rivers. Other studies have dealt with the soils (Sioli, 1966) and the sedimentary loads (Gibbs, 1967). For this reason, this study did not concentrate on water quality but on decomposition and nutrient cycling .

This research was sponsored by the Instituto Nacional de Pesquisas da Amazônia (INPA) and was conducted from Manaus, Brazil. Some of the analyses were done at the School of Forestry, UIniversity of Montana, Missoula, Moritana. The study site for spodosols was west of Manacapuru on the Rio Manacapuru, while that for the oxisols was a soil of intermediate character on the new Punta Negra road out of Manaus, Brazil.

In this report, "igapó" refers to flooded areas with black water, while "varzea" refers to periodically flooded white water areas adjacent to oxisols. "Campina" refers to a special type of forest $(10 \mathrm{~m})$ rich in epiphytes and growing on white sands (spodosols).

\section{NETHODS}

\section{LITTER DECOMPOSITION - TERRESTRIAL AND AQUATIC}

Leaves of Caryocar villosum (Aubl.) Pers. (Pequia) were dried at $100^{\circ} \mathrm{C}$. for 24 hours and packaged in $2 \mathrm{~mm}$ nylon mesh bags stitched with nylon line. This genus was selected for testing since it has species in or near both sites. Three hundred and twenty bags were prepared with one dry leaf per bag and were numbered. These bags were subjected to the following treatments:

\footnotetext{
A. Black Water - Terrestrial, Spodosol 5 bags each month for four months. Control (distilled water)
}

Fungicide $(10 \mathrm{~g}$ Benlate, $10 \mathrm{~g}$ Dithane in $5 \mathrm{~L}$ water)

Bacteriocide (5 g streptomycin sulfate in $5 \mathrm{~L}$ water)

Insecticide (100 m "Detefon" (1) in 5 L water)

B. Black Water - Aquatic (Igapó) (beneath $1-3 \mathrm{~m}$ of water)

Control (Control and treatments the same as under A)

Fungicide

Bacteriocide

Insecticide

C. White Water - Terrestrial, Oxisol (5 bags each month for four months). Control (Control and treatments the same as under A)

Fungicide

Bacteriocide

Insecticide

D. White Water - Varzea - Aquatic (beneath 1-3 $\mathrm{m}$ of water)

Control (treatments the same as un$\operatorname{der}$ A)

Fungicide

Bacteriocide

Insecticide

Thus eighty samples were set out on each of the four sites (A-D) in late August. Once a month for four months, five samples were brought in from each test ( 80 bags per month) monthly. The bags were placed in a refrigerator at $2^{\circ} \mathrm{C}$. until they could be examined under a dissecting scope for the numbers of Arthropods and fungal hyphae present in ten fields $(0.5 \mathrm{~cm}$ diameter $)$ on the lower side of each leaf. Plans to run bacterial counts on a portion of these leaves failed, although a few counts were taken. The leaves were then dried at $100^{\circ} \mathrm{C}$. for 24 hours and weighed to determine actual weight loss on a percentage basis. One gram of the dried leaf material was extracted for total cellulose content while another 1 gram sample was ground and homogenized for the determination of $\mathrm{Ca}, \mathrm{Cu}$, $\mathrm{Fe}, \mathrm{K}, \mathrm{Mg}, \mathrm{Mn}, \mathrm{Na}$, and $\mathrm{Zn}$ using a Techtron

(1) - Fosfato - Dimetil - Dichlorovin $1,50 \%$. Bromophos $0.89 \%$. Pinetras $0.08 \%$. Sulfoxide. 
AA-5 atomic absorption spectrophotometer and standard ashing procedures at $525^{\circ} \mathrm{C}$. for two hours. The weights of dried leaf material used for cellulose determination were determined by volume so that changes in cellulose content relative to volume could be made. The cellulose content and elemental content of the leaves was determined on dried leaves before placing them in the field and at monthly intervals after they were placed in the field.

The packets which remained in the field were retreated with the same strength of reagents in September and October, although there is little reason to believe that those samples actually placed under water retained these chemicals for a long enough period to have any effect on decomposition. The insecticide may have been somewhat effective because of the oily nature of "Detefon".

By studying the changes over time between leaves on land and in the water, and between leaves on spodosols and oxisols in terms of cellulose, elemental content, Arthropods, percent ash and fungi, it was hoped that a clearer understanding of the dominant factors in decomposition might be recognized, and hopefully provide an explanation for the differences in origin between black and white water.

Associated with the decomposition study were measurements of soil temperature at 3 $\mathrm{cm}$, water temperature at $3 \mathrm{~m}$, oxygen content (Winkler Method) and $\mathrm{pH}$ of the water at 3-5 $\mathrm{m}, \mathrm{pH}$ of the soil at $0-5$ and $20-25 \mathrm{~cm}, \mathrm{pH}$ of rainfall and thrufall and $\mathrm{pH}$ and elemental content of litter leachate. The content of IN $\mathrm{NH}_{4} \mathrm{OAc}$ extractable $\mathrm{Ca}, \mathrm{Cu}, \mathrm{Fe}, \mathrm{K}, \mathrm{Mg}, \mathrm{Mn}$, $\mathrm{Na}$ and $\mathrm{Zn}$ from $0-5 \mathrm{~cm}$ and $20-25 \mathrm{~cm}$ so:l samples was measured using the atomic absorption spectrophotometer for the cations. Total nitrogen was determined by the modified microkjdahl procedure. These data were needed to characterize the soil chemistry of the main terrestrial study sites, and to determine how different these areas actually were in soil chemistry. Some "typical" oxisol and spodesol sites were also analyzed to see how representative the study sites actually were, and to compare soil nutrient content to tree height.

\section{RESULTS AND DISCUSSION}

\section{Litter decomposition - Initial studies}

An immediate problem arose with the decomposition study because the harvester ants on the "terra firme" sites quickly carried off all but the leaves treated with insecticide. The insecticide packets had a smaller mesh (1 $\mathrm{mm}$ ), but not enough to stop the ants since they cut through the heavier, tougher plastic of the $2 \mathrm{~mm}$ mesh bags. Ants were also found on leaves submerged under water. The position of each packet also proved to be critical. Those packets which were in contact with the thin humus layer decomposed more rapidly than those placed on top of freshly fallen litter. The leaves used are quite high in $\mathrm{Ca}$, $\mathrm{N}, \mathrm{P}$ and other elements. It is possible that the ants can detect high nutrient levels in the leaves, and so, selected these dry leaves.

Observations suggest that the litter requires a "softening period" of several weeks or more on the surface before they readily attacked by either fungi or litter animals. This allows time for moistening, bacterial action, and settling into the moist microclimate of the lower litter. Counts of animal feces as an indication of animal activity on "new" and "old" leaves from the forest floor of spodosols showed 0.24 feces $/ \mathrm{mm}^{2}$ on new freshly fallen leaves and $1.09 \mathrm{feces} / \mathrm{mm}^{2}$ on old leaves which were softened and partly decomposed. Oxisol new litter fall had 0.59 feces $/ \mathrm{mm}^{2}$ while old leaves had $7.26 \mathrm{feces} / \mathrm{mm}^{2}$ suggesting greater animal activity on oxisol litter compared to spodosol litter. Litter extractions also showed 20.5 animals (aquatic) per 250 $\mathrm{cm}^{3}$ from "igapó" litter, $150 / 250 \mathrm{~cm}^{3}$ from spodosol "terra firme" litter, $28.0 / 250 \mathrm{~cm}^{3}$ from "Campina" litter, $90.4 / 250 \mathrm{~cm}^{3}$ from oxisol new leaf litter, $261.8 / 250 \mathrm{~cm}^{3}$ from oxisol old leaf litter, and only $3.0 / 250 \mathrm{~cm}^{3}$ from "Varzea" litter.

Preliminary studies also included fungal counts as the number of fungal hyphae $/ \mathrm{mm}^{2}$. The new leaves from the spodosols averaged 0.647 hyphae $/ \mathrm{mm}^{2}$, while the old leaves averaged 0.981 hyphae $/ \mathrm{mm}^{2}$. The "igapó" had only 0.25 hyphae $/ \mathrm{mm}^{2}$. Some of which could 
have been on the leaf when it fell into the water. Oxisol new leaf litter had 0.815 hyphae $/ \mathrm{mm}^{2}$ while old litter had 0.923 hyphae/ $\mathrm{mm}^{2}$; suggesting in most cases that older leaves are more readily attacked by fungi.

Another study showed an average $\mathrm{pH}$ of leaf surface scrapings from black water litter of 3.45 , while the corresponding terrestrial litter showed a pH of 5,10. Spodosol terrestrial litter had a surface $\mathrm{pH}$ of 4.85 while the aquatic litter, "Varzea", had 5.40.

The $\mathrm{pH}$ of surface leaf scrapings seemed important because of the large number of bacteria cultured from the surface of aquatic litter in some trial dilutions. The black water "igapó" litter with a pH of 3.45 and an oxygen level of from 0.22 to $0 \mathrm{mg} / \mathrm{l}$ would defintely favor anaerobic, acidic bacteria while the higher $\mathrm{pH}$ range of the "varzea" litter $(5.40)$ would favor a different bacterial flora. The abundance of bacteria in both aquatic litter sites strongly suggests a bacterial dominated decomposition pattern resulting in a high output of organic particulates. Areas of the "varzea" which have white water during high water have been observed to turn to black water as the water goes down and side channels stagnate. Much of the differences between black and white water may be explained by the rate of flow of the water, its sediment load and settling rate, the $\mathrm{pH}$ and oxygen content, what types of organisms are the dominant decomposers, and what their final metabolic end product is chemically.

\section{Decomposition of Caryocar villosum leaves}

Table 1 shows the weight losses as percent of the original dry weight for the leaves used in this study. Although only one species was used, it should give an indication of the general types of organisms which dominate decomposition on spodosol and oxisol terrestrial and aquatic sites.

The control leaves showed rapid weight loss after one month to ants on the spodosol site (Fig. 1). The inundated leaves in the "igapó" (black water) lost about $50 \%$ of their dry weight in the first two months, and then leveled off with little additional weight loss. This pattern suggests bacterial decomposition with little or no succession when the bacterial substrate (p;esumably an organic) is used up, the decomposition slows because few other organisms are able to take over, once the organics are depleted. "Igapó" leaves under water become thinner with little evidence of chewing or breaking. However, the season of heavy larval infestations did not come until the end of the study. Mayfly and midge larvae may be very important at some times of the year. The build-up of $\mathrm{Fe}, \mathrm{Ca}, \mathrm{Mn}, \mathrm{P}, \mathrm{K}$ and $\mathrm{Mg}$ in "igapó" litter with time (Table 2) strongly suggests that this is what occurs. Once the water recedes, the animal and fungal decomposition pattern can return using carbohydrate from softened new litter fall. High $\mathrm{N}$ content in the litter would certainly encourage more rapid microbial colonization once the $\mathrm{pH}$ is raised and oxygen returns to the system.

Control (untreated) litter on oxisols decomposed in about 2.5 months with heavy litter animal activity and considerable root-leaf contact suggesting some "direct nutrient cycling" (Went and Stark, 1968).

All leaves placed in the white water "var. zea" were taken by humans.

When bacteriostat treated leaves were exposed on the spodosol site, ants quickly destroyed these leaves which are rich in nutrients (Fig. 1). The "igapó" litter probably did not retain the bacteriostatic agent, and leaf decomposition closely resembled that of the controls from the "igapó". It is possible that the $\mathrm{pH}$ of the "igapó" bottom sediments becomes too low after months of stagnation and flooding so that the active bacteria may be inhibited or slowed by their own acid $(\mathrm{pH}$ 3.45 ). Leaves placed on the oxisol site decomposed in about four months when treated with bacteriostatic agents suggesting that bacteria may be essential in the initial "softening " process on land, and to a lesser extent in later decomposition.

Leaves treated with fungicide were also attractive to the ants and disappeared within one month after exposure. The leaves placed 


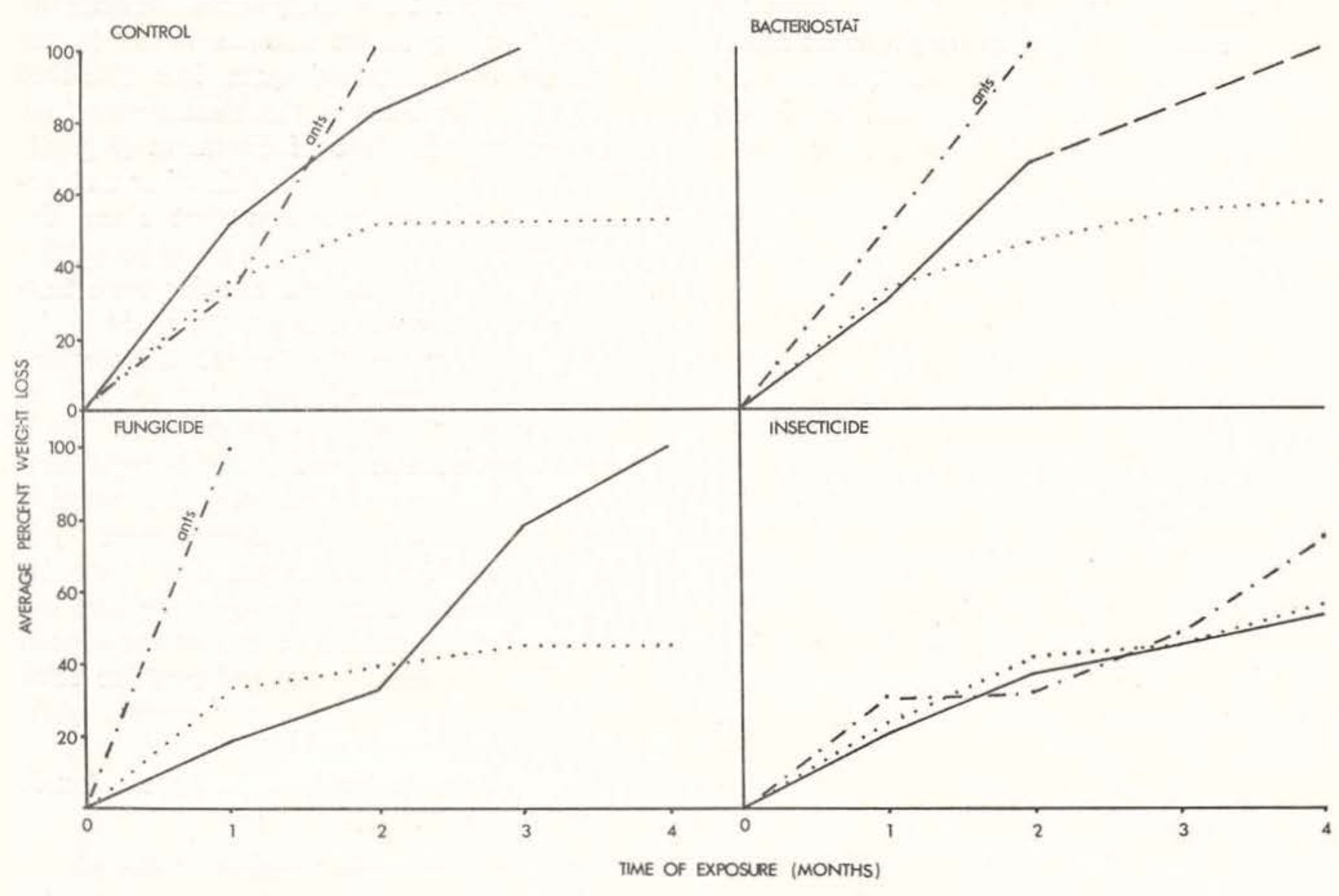

Figure 1. Average percent weight loss with time and treatment for Caryocar villosum leaves,

Blackwater Terra Firme _ _ _ Blackwater Igapó . . . . Whitewater Terra Firme

in the "igapó" decomposed rapidly for the first month and then leveled off in weight loss as did the controls. Fungicide treated leaves in the "igapó" lost slightly less weight $(7 \%)$ than did the controls suggesting a possible minor role of aquatic fungi in decomposition. The leaves placed on the oxisol site lost nearly all their weight in four months when treated with fungicide (Table 1). The fungicide retarded weight loss by one month suggesting that fungi are relatively important decomposers on the oxisols. The slowed weight loss during the second month is the result of severe drying. Nutrient loss from all treatments on the oxisol site were minimal tending to change little from month to month which is characteristic of a decomposer which "eats" whole parts and does not selectively choose only one substrate within the leaf. There are insufficient data on cellulose content for interpretation.
Figure 1 shows that decomposition on all sites, aquatic and terrestrial, was gradual and nearly identical from month to month for insecticide treated leaves. The leaves did not disappear in four months time and had lost only between 50 and $75 \%$ of their original dry weight. The data and observations suggest that litter animals (mites, collembola, insect larvae) are extremely important on the oxisols and nearly as important on the spodosol terrestrial sites. In the water, midges and mayfly larvae were found indicating some importance in the aquatic habitat of aquatic insects. It is too bad that bacterial counts could not have been made to establish the relative importance of aquatic insects and bacteria in decomposition under water. The abundance of bacterial slimes strongly suggests an aquatic decomposition pattern dominated by bacteria; with insects of lesser importance. 
The leaves on the black water "terra firme" site lost slightly more weight in the fourth month than did the other leaves. This difference could be attributed to control of fungal eating insects which allowed greater fungal growth. Data to date indicate that fungi are extremely important on the spodosols as decomposers, and particularly mycorrhizal fungi.

\section{Elemental Content of Vegetation}

Only one species of leaves, Caryocar villosum, was selected for study because of the complexity of using the natural mixed litter. If mixed litter is used in decomposition studies, then it is essential to use exactly the same weight of each type of leaf, including the same weight of petiole versus blade. This handling of litter is extremely difficult and time-consuming.

Unfortunately, the harvester ants were attracted to the control leaf packets on the spodosol site and they completely destroyed these samples after the first month. The rapid disappearance of litter as a result of ants is an indication of the importance of these Arthropods to decomposition. They also destroyed the entire fungicide study within the first month. People removed all of the samples placed in the water of the "varzea" site within the first month. Drying on the "terra firme" sites (spodosol and oxisol) occurred in September because of the dry season. The data cannot be extrapolated to other sites or times of year. Control of fungal or bacterial growth has limited effect if the season is too dry to allow their growth. Full data for four months is available from the black water "igapó" innundated site.

Table 2 shows the $\mu \mathrm{g} / \mathrm{g}$ of ten biologically important elements, percent ash, and total cations for the two study sites, three treatments, and innundated versus "terra firme" sites.

In general, Ca decreased slightly with time in the decaying leaves in the "igapó" site under inundation (Fig. 4). It should be remembered that these data are on a dry weight basis and the carbon content was continually changing resulting in periodic comparisons which are not truly comparable. Magnesium showed no significant changes in the leaves with time and remained quite low (245-1800 $\mu \mathrm{g} / \mathrm{g}$. Iron increased in the black water "igapó" leaves regardless of treatment (Fig. 4). The "igapó" site may be considered as an inundated control decomposition test since the chemicals used in the treatments were quickly leached away. The aquatic samples were treated so that they would begin the study in the same condition as the terrestrial samples. Manganese increased considerably in the leaves in the "igapó" site as did iron. These two elements are not readily used by organisms in high concentrations, so they are probably selected against by the decomposers. The least change of all treatments was in the insecticide treated samples suggesting that the chemical used limited all forms of decomposition. This chemical is oily and tends to stick to surfaces. Copper and zinc changed slightly in the leaves over the four months with a slight tendency to increase during the fourth month (Table 2).

The total nitrogen content of the leaves in all surviving tests tended to increase by the second month and then decreased through the fourth month (Fig. 5). The absolute levels of nitrogen probably reflect the nitrogen of the decomposers and their waste products, so that it is impossible to separate completely the protoplasm of the decomposer from that of the substrate. Nitrogen levels were high in the litter ranging from 28,900 to $49,140 \mu \mathrm{g} / \mathrm{g}$. Litter with these levels of nitrogen are ideal sources of nitrogen needed for plant growth which suggests that direct nutrient cycling can be of great value to growing vegetation. The insecticide treated samples had the lowest levels of nitrogen suggesting that the animal populations normally enrich the litter considerably with their feces. The insecticide treated leaves had levels of nitrogen somewhat lower than that of the controls.

Potassium remained low and stable in the litter samples regardless of treatment (290$1000 \mu \mathrm{g} / \mathrm{g}$, Table 2).

Phosphorus was moderately high in the litter (2140 to $69 \mu \mathrm{g} / \mathrm{g}$, Table 2). Surprisingly, 
the phosphorus levels did not fluctuate much during the four months of the study. The highest levels of phosphorus was in the control and bacteriostat treated leaves, with the least change and lowest levels in the insecti- cide test ( 3110 to $5370 \mu \mathrm{g} / \mathrm{g}$ ). Oxisol ("terra firme") and spodosol ("igapó") sites showed the greatest difference in litter phosphorlis in the bacteriostat test (Fig. 5). Midge larvae were seen to be quite active on the "igapó"

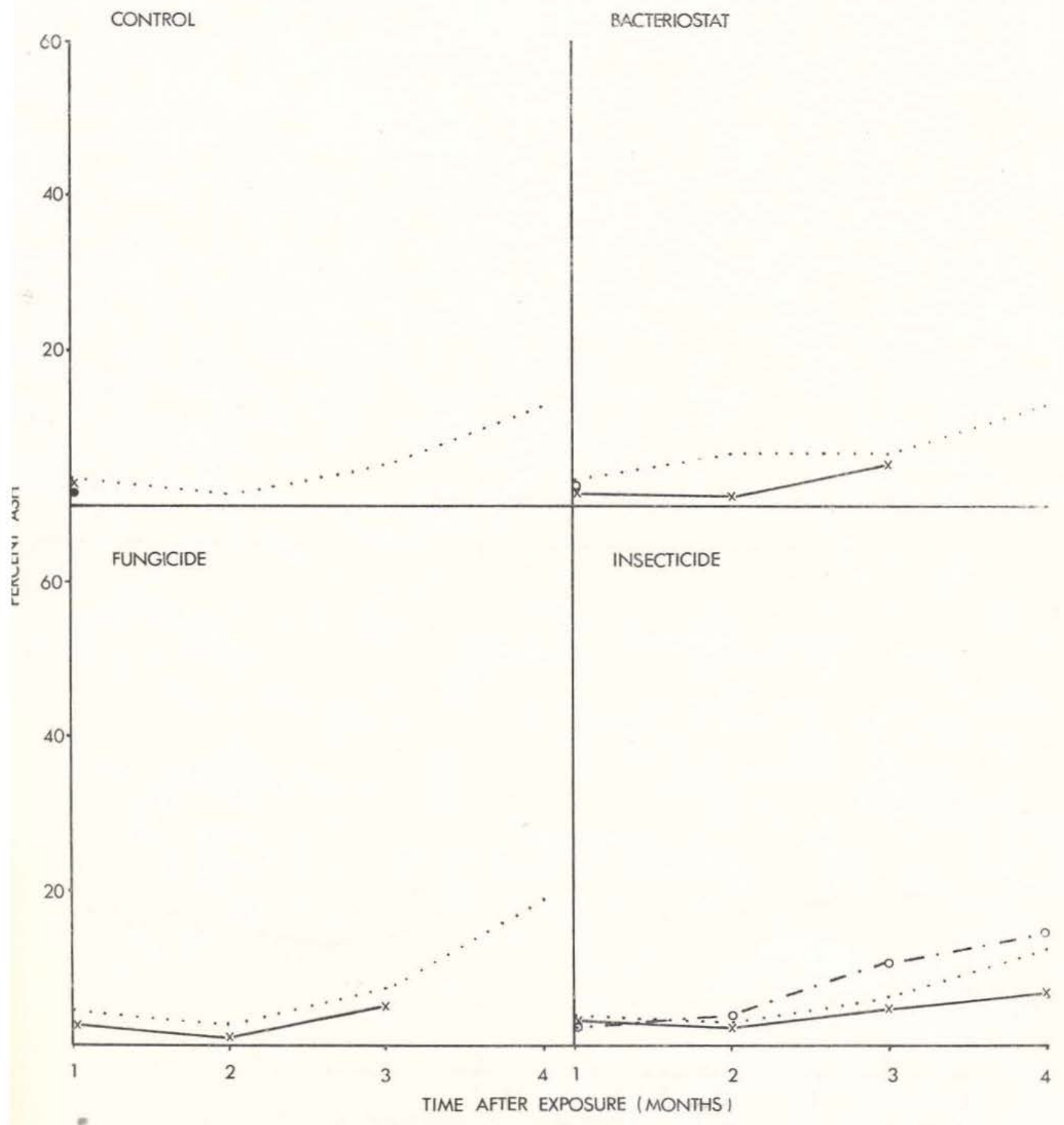

Figure 2. Changes in the average ash content (\%) in Caryocar villosum leaves with treatment and time. Spodosol _ _, , - Oxisol $\mathrm{x} \longrightarrow \mathrm{x}$ Blackwater Control 
litter. These organisms may contribute some phosphorus to the decaying leaves. The treatment did not eliminate bacteria which are important in the aquatic decomposition sites and are also high in phosphorus.
Data on the percent ash content (Fg. 2) tended to increase with time for all treatments. The ash content of the controls was 1.8 to $12.62 \%$ (Table 2, Fig. 2). The ash content of the bacteriostat tests on the oxisols increased

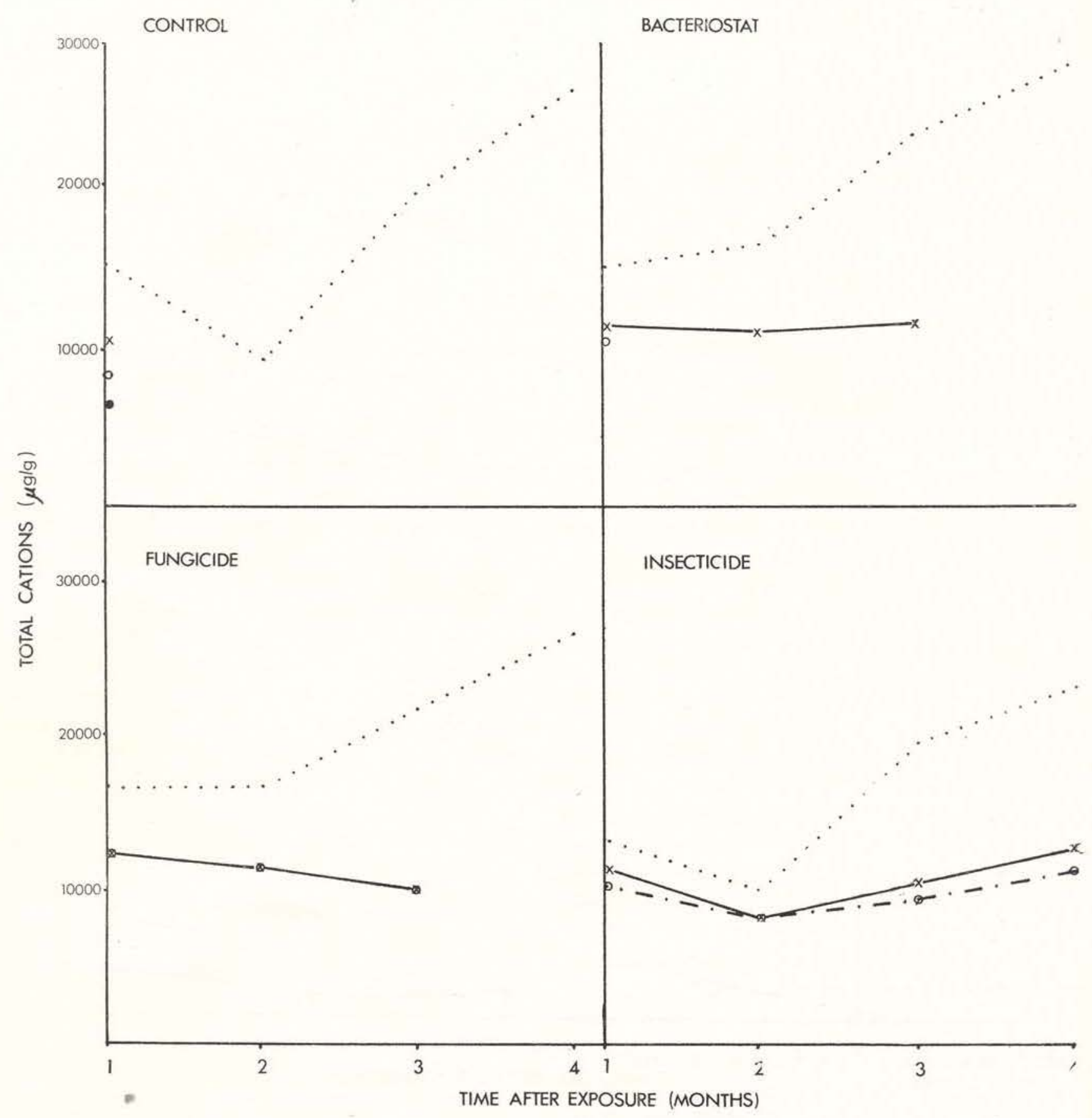

Figure 3. Changes in the total cation content of Caryocar villosum leaves by weight, time and by treatment. Spodosol _ - Oxisol — Blackwater . Initial • Before Exposure 
from 1.6 to $5.88 \%$, while that on the black water "igapó" site changed from 3.54 to $13.24 \%$ (Table 2). The ash content of the fungicide treated leaves changed on the oxisol sites from 2.82 to $4.86 \%$, and increased on the black water "igapó" site from 4.04 (decreased to 2.92 in the second month) then increased to $19.04 \%$. It is nearly impossible to interpret these changes in percent ash without corresponding data on cellulose con-

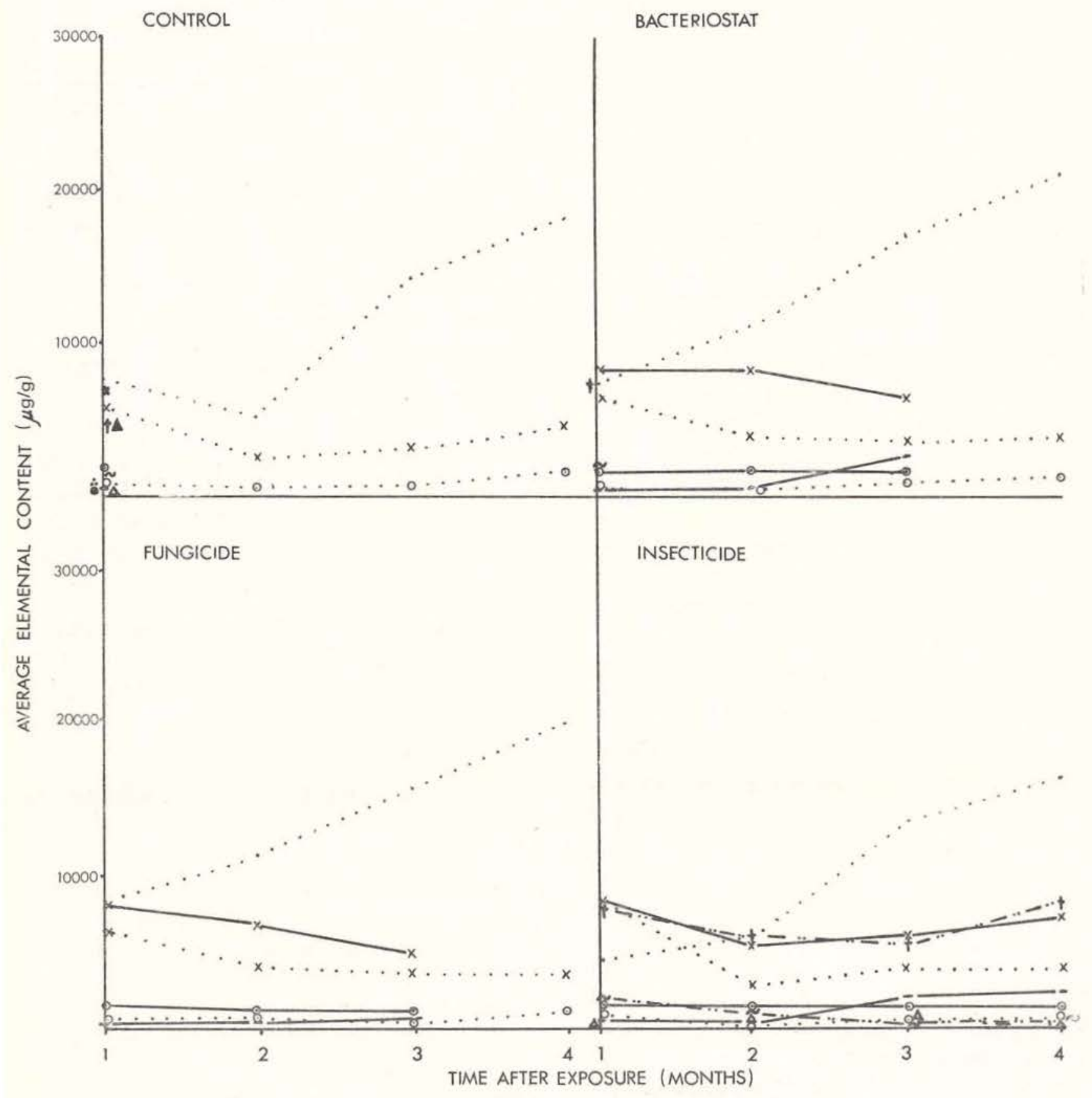

Figure 4. Changes in the average $\mathrm{Ca}, \mathrm{Mg}$, and Fe content in Caryocar villosum leaves with treatment and time.
$\mathrm{Ca}+-. .+\dagger$
Spodosol $\mathrm{Mg}-\ldots-\sim$
$\mathrm{Ca} \mathrm{x}$
$\mathrm{Ca} \mathrm{x}, \ldots \mathrm{x}$
Fe $\Delta-. .-\Delta$
Oxisol $\mathrm{Mg} \mathbf{0}-\mathrm{O}$
Blackwater $\mathrm{Mg} 0$ :... o
Ca $\mathbf{A}$
Fe - - -
$\mathrm{Fe}$.
Original $\mathrm{Mg} \bullet$
$\mathrm{Fe} \therefore$ 
tent. The ash content of leaves treated with insecticides changed from 2.70 to $14.94 \%$ on the spodosol, from 3.20 (decreased to 2.72 in the second month, then increased to $7.16 \%$, and from $3.92 \%$ for the black water "igapó" site to $13.14 \%$.

The initial level of ash in the untreated, unexposed leaves was 3.31 to $3.36 \%$ (Table 2), so that many tests showed a slight decline in ash content during the first month. This decrease in ash content is not easy to explain without cellulose data. In nearly all cases, the individual elements increased in concentration on a dry weight basis $(\mu \mathrm{g} / \mathrm{g})$ after one month's exposure. This is probably the result of removal of cellulose and hydrocarbons leaving relatively more of each element behind.

Total cations were calculated in $\mathrm{rg} / \mathrm{g}$ for the eight cations measured as an indication of the changes brought about by the treatments and exposure time (Table 2). The total cation content varied from 8355 to $28,772 \mu \mathrm{g} / \mathrm{g}$. The controls which were untreated had 8,418 to $10,876 \mu \mathrm{g} / \mathrm{g}$ while the unexposed and untreated leaves had 6628 to $6723 \mu \mathrm{g} / \mathrm{g}$ of total cations at the start of the tests. The total cation content increased most drastically in the "igapó" sites regardless of treatment (Fig. 3). The total cations changed little on samples placed on oxisols and those on terra firme spodosols. Decomposition on the "igapó" sites appears to be selective removing some materials and not others as is the case with bacterial and some types of fungal decay where a specific substrate is required. When the insects were not controlled on terra firme sites, the decomposition appeared to be less selective with the disappearance of whole leaf segments and without a selective concentration of total of specific cations. The oxisol sites appear to be strongly dependent on litter animals for decomposition with a lesser dependence of spodosol litter on animal decomposers.

Litter from the bottom of black water streams had high ash contents $(28.26$ to $28.48 \%$ ) and low total cations (2544 to 2753 $\mu \mathrm{g} / \mathrm{g}$. Table 2). Those data suggest that some element not measured in the eight cations is present in great quantities in the black water areas. Silicon is one element which may be very high in the decomposing "igapó" litter, but was not measured here. Similar discrepancies exist between other sites where total cations and percent ash were measured, probably for the same reason. In addition, these plants were digested by dry ashing at $525^{\circ} \mathrm{C}$. which means that elements such as silica will not go into solution, while others such as nitrogen will volatize during ashing. For this reason, total nitrogen was determined from a wet digestion of $0.1 \mathrm{~g}$ samples by the $\mathrm{mi}$ crokjeldahl procedure. Percent ash and total cations cannot be expected to agree under these circumstances.

Other "igapó" sites showed 10,394 to $10,562 \mu \mathrm{g} / \mathrm{g}$ of total cations, and 16.39 to $17.53 \%$ ash (Table 2). Campina Creek litter (inundated) was low in both percent ash (7.58-7.62\%) and total cations (1434-1457 $\mu \mathrm{g} / \mathrm{g}$ ) which is a direct reflection of the low elemental content of "campina" vegetation and soil in general.

Litter from oxisol soils showed 9,264 to $9,402 \mu \mathrm{g} / \mathrm{g}$ total cations and 9.13 to $9.18 \%$ ash, a reflection of a slightly richer site, but one which is poor from severe leaching (Table 2).

"Varzea" litter had very high total cations $(13,134$ to $13,786 \mu \mathrm{g} / \mathrm{g})$ and high percent ash $(68.23$ to $68.7 \%)$ indicating a nutrient rich river bottom litter capable of releasing large amounts of cations and anions, and enriching the soil when the waters subsided (Table 2). The "varzea" litter was noticeably low in nitrogen $(5,740 \mu \mathrm{g} / \mathrm{g})$ compared to $14,000 \mu \mathrm{g} / \mathrm{g}$ for "igapó" litter. High levels of $\mathrm{Mg}, \mathrm{Cu}, \mathrm{Fe}$, $\mathrm{K}$ and $\mathrm{Zn}$ were found in the "varzea" litter (inundated). It is interesting that the soil also showed relatively high levels of $\mathrm{Mn}, \mathrm{Mg}, \mathrm{K}$, and $\mathrm{Zn}$, but low levels of $\mathrm{Fe}$. The balance of $\mathrm{Fe}$ in the decomposing litter could well influence what kinds of microorganisms can and will 


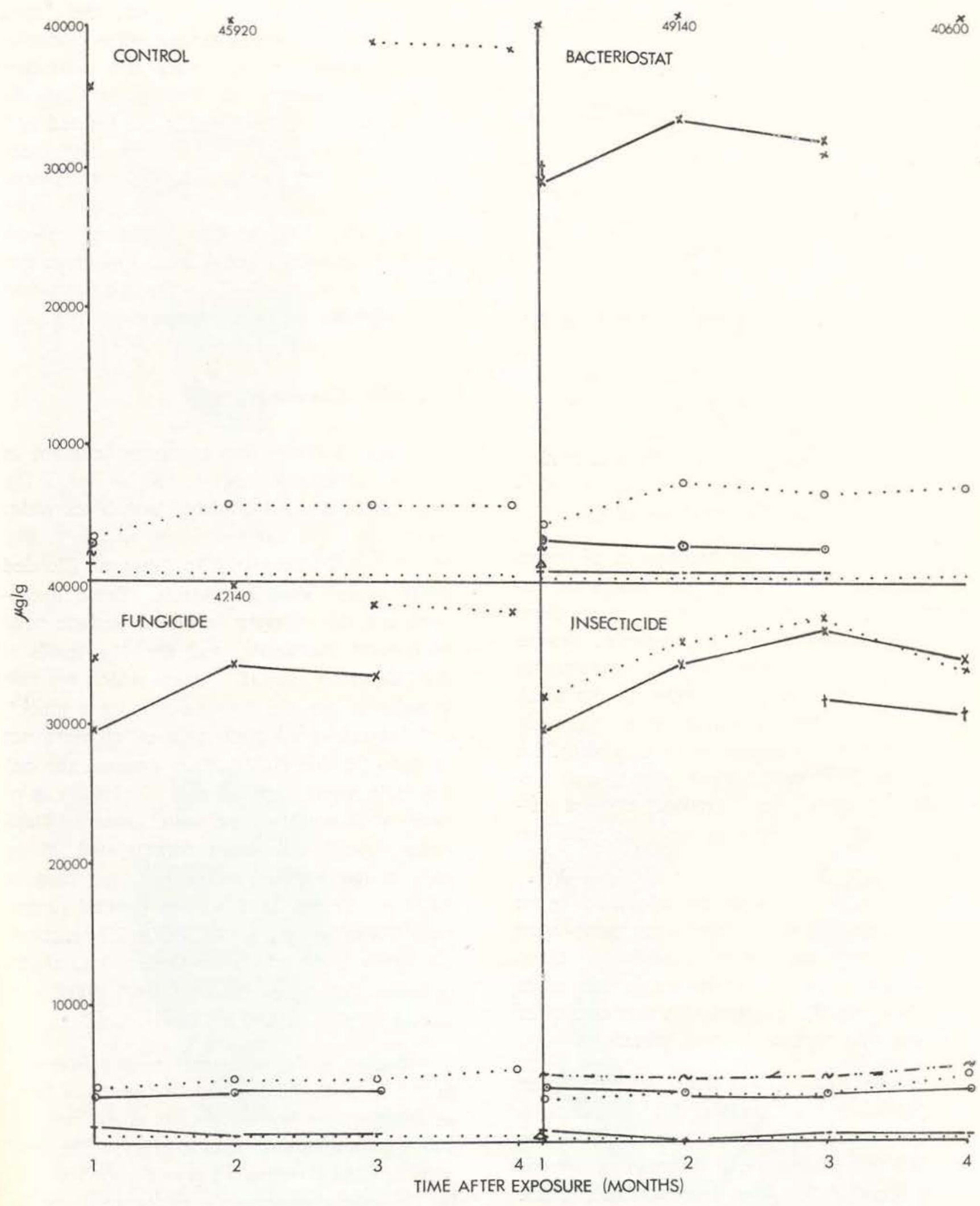

Figure 5. Changes in the $\mathrm{N}, \mathrm{P}$, and $\mathrm{K}$ content of Caryocar villosum leaves with treatment and time. Spodosol

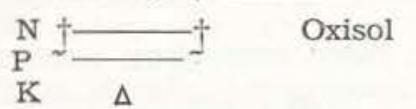
$\mathrm{N}-\mathrm{X}$
$\mathrm{P}-\mathrm{X}$
$\mathrm{K}-\longrightarrow-0$ Blackwater $\begin{array}{llll}\mathrm{N} & \mathrm{x} & \ldots & \mathrm{x} \\ \mathrm{F} & 0 & \cdots & 0\end{array}$ K . . . 
decompose the litter. Conditions in the "varzea" would favor bacterial decomposition where iron is a possible active agent.

In general, the levels of elements in the "terra firme" litter agrea with those from a former study on spodosols (Stark, 1971). The Caryocar leaves represent only one species while the litter analyzed in 1971 represents a conglomerate of many species with generally lower $\mathrm{Cu}, \mathrm{Fe}, \mathrm{Mn}, \mathrm{Zn}, \mathrm{Ca}, \mathrm{Mg}, \mathrm{N}$, and $\mathrm{P}$.

The elemental analyses of litter from land and water from white and black water areas has shown some distinctive difference in elemental content and decomposition pattern. Unfortunately, the data on bacterial activity in these sites could not be determined. Studies of microbial ATP would provide the kœy information needed to interpret these data.

Figs. 6-10 show the appearance of leaves of Caryocar after different treatments and exposure time in the field. Unfortunately, there are no photographs of the controls. Leaves treated with fungicide show considerable fragmentation after four months in the black water "igapó" but the leaves were noticeably thin. There is no reason to believe that the treatment persisted. Leaves treated with fungicide on "terra firme" (oxisol) showed evidence of chewing and fragmentation after two months (Fig. 6).

Leaves treated with bacteriostatic agent and placed on "terra firme" (spodosol) were nearly completely decomposed after three months and were heavily infiltrated with roots and fungi (Fig. 7). It is probable that control of bacteria allowed rapid fungal growth.

Leaves treated with bacteriostatic agent and placed in black water did not show a strong effect of the chemical because of leaching, but the leaves were fragmented on the edges (Figs. 7, 8). After four months in black water, the leaves were heavily fragmented. Bacteriostat treated leaves on oxisol "terra firme" showed progressive fragmentation, insect damage, and root actitivy (Fig. 8).
When insecticide was used, the "terra firme" spodosol leaves did not show extensive insect damage. Insects were not prominent during the months of this study, and the leaves placed in black water and treated with insecticide showed little decomposition and almost no insect damage (Fig. 9). Leaves placed on oxisol "terra firme" were heavily fragmented after four month's exposure. Roots and fungi appear to have been important during the fourth month (Fig. 10), but there was little evidence of insect damage.

\section{Elemental Content of Soils}

Table 3 shows the elemental content of various spodosols and oxisols in $\mu \mathrm{g} / \mathrm{g}$. The first ten soils are associated with black water rivers and are extremely low in $\mathrm{Ca}, \mathrm{K}, \mathrm{Mg}$, $\mathrm{Mn}, \mathrm{N}$ and $\mathrm{Zn}$ compared to "varzea" (flooded white areas) sites or oxisols. Some exceptions are the nitrogen levels of surface soils on lowand spodosols, and the Mg levels of the "Campina" forest. Areas which are rich in calcium are the "varzea inundated muck", and "varzea" bank sediments which were not recently flooded (Table 3 ). In general, the oxisol soils were quite low in $\mathrm{Ca}(10-26 \mu \mathrm{g} / \mathrm{g})$ even when earth worms were present. Black water "igapó" (drowned forest) had $26 \mu \mathrm{g}$ $\mathrm{ca} / \mathrm{g}$ at the surface, and only $15 \mu \mathrm{g} \mathrm{ca} / \mathrm{g}$ at 20-25 cm depth. Spodosols in general ranged from 9.5 to $26 \mu \mathrm{g} / \mathrm{g}$ for $\mathrm{IN} \mathrm{NH} \mathrm{N}_{4} \mathrm{OAC}$ extractable $\mathrm{Ca}$. These levels of $\mathrm{Ca}$ are the same to slightly lower than those reported from Brazil spodosols in 1971 (Stark, 1971).

Copper in the spodosols ranged from 0.8 to $2.5 \mu \mathrm{g} / \mathrm{g}$ (Table 3) which is about the same as those values from an earlier study from the same general areas (Stark, 1971). The best soils studied ("varzea") showed only $3.0 \mu \mathrm{g} / \mathrm{g}$ for $\mathrm{Cu}$ indicating generally widespread low levels for this element.

Extractable iron content ranged from 0.8 to $22.5 \mu \mathrm{g} / \mathrm{g}$ for the spodosols, with not over 

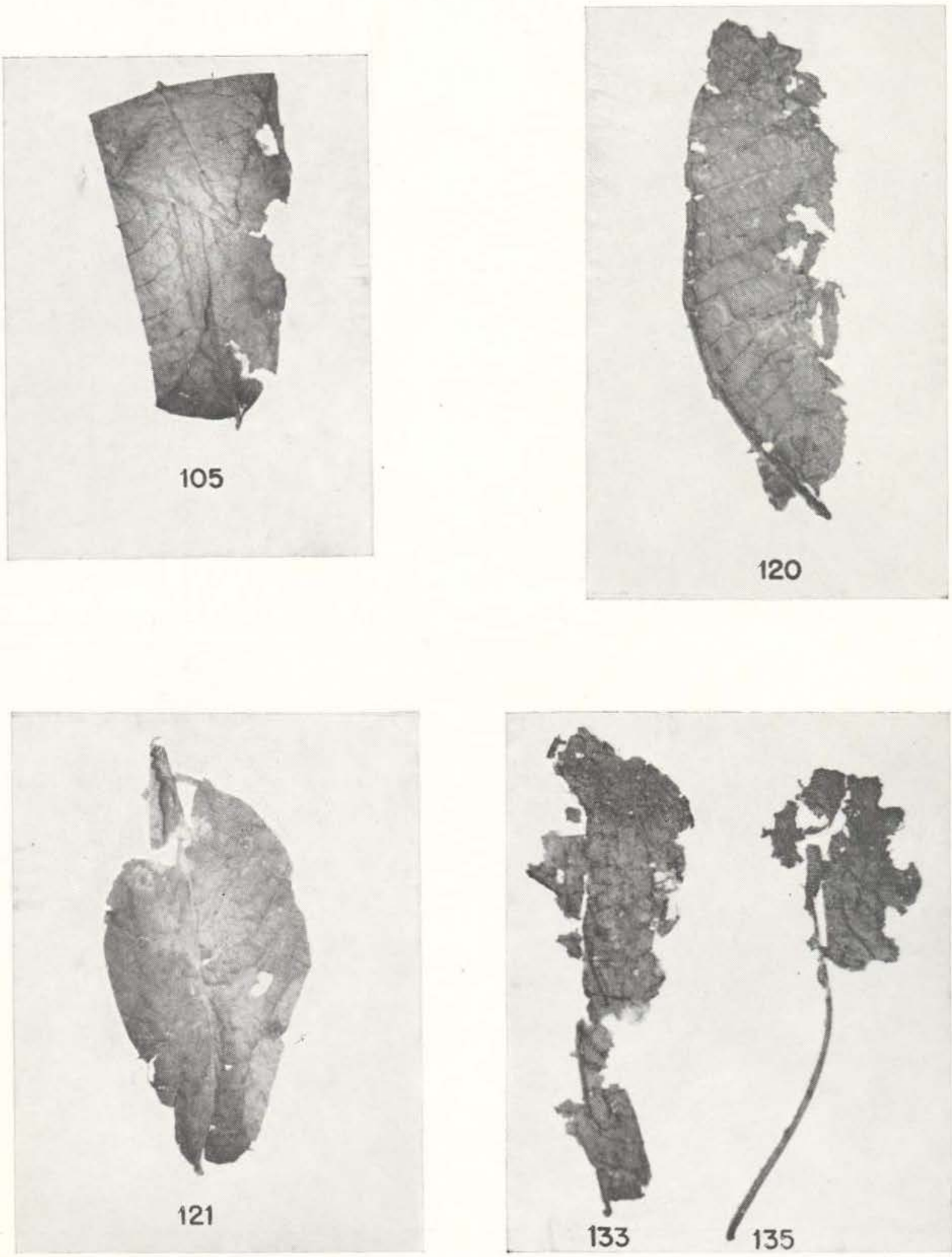

Fig. 6. Nos. 105, 120. Leaves of Caryocar treated with fungicide and placed in black water "igapó" for one and four months respectively. Nos, 121, 133-135. Leaves treated similarly but placed on oxisol "terra firme" for one and three months respectively. 

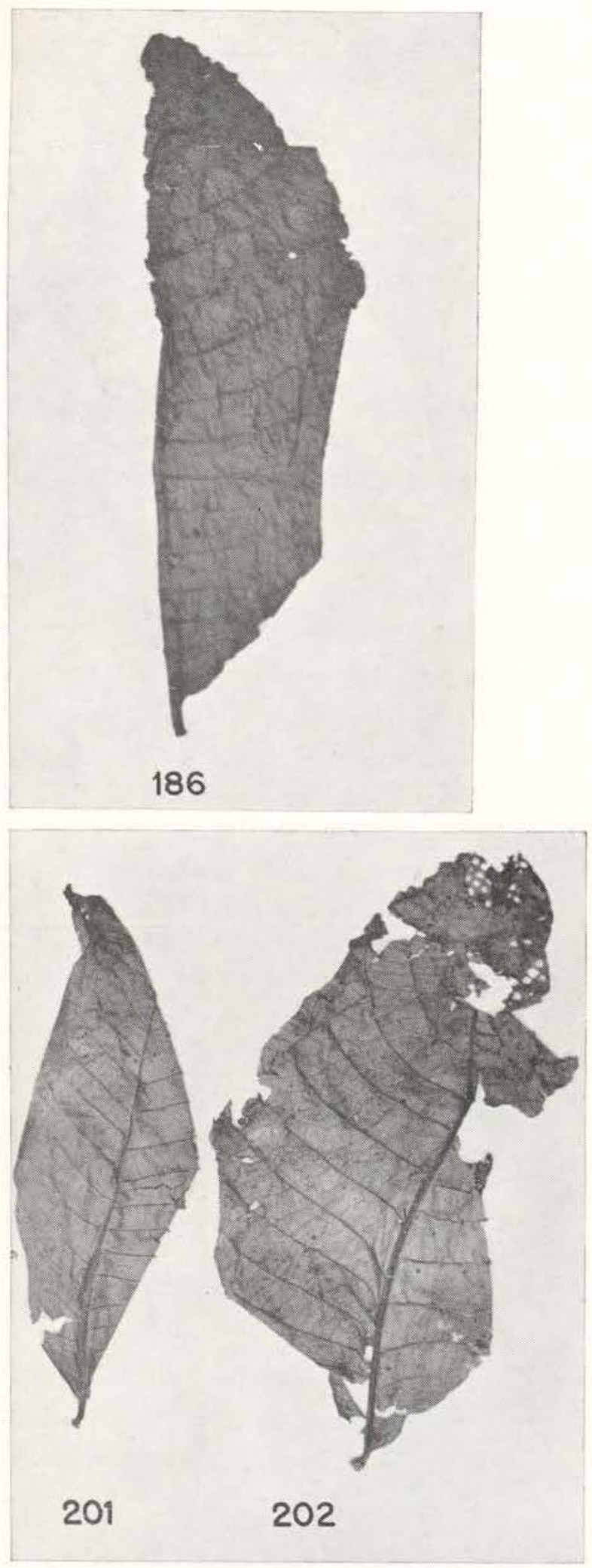
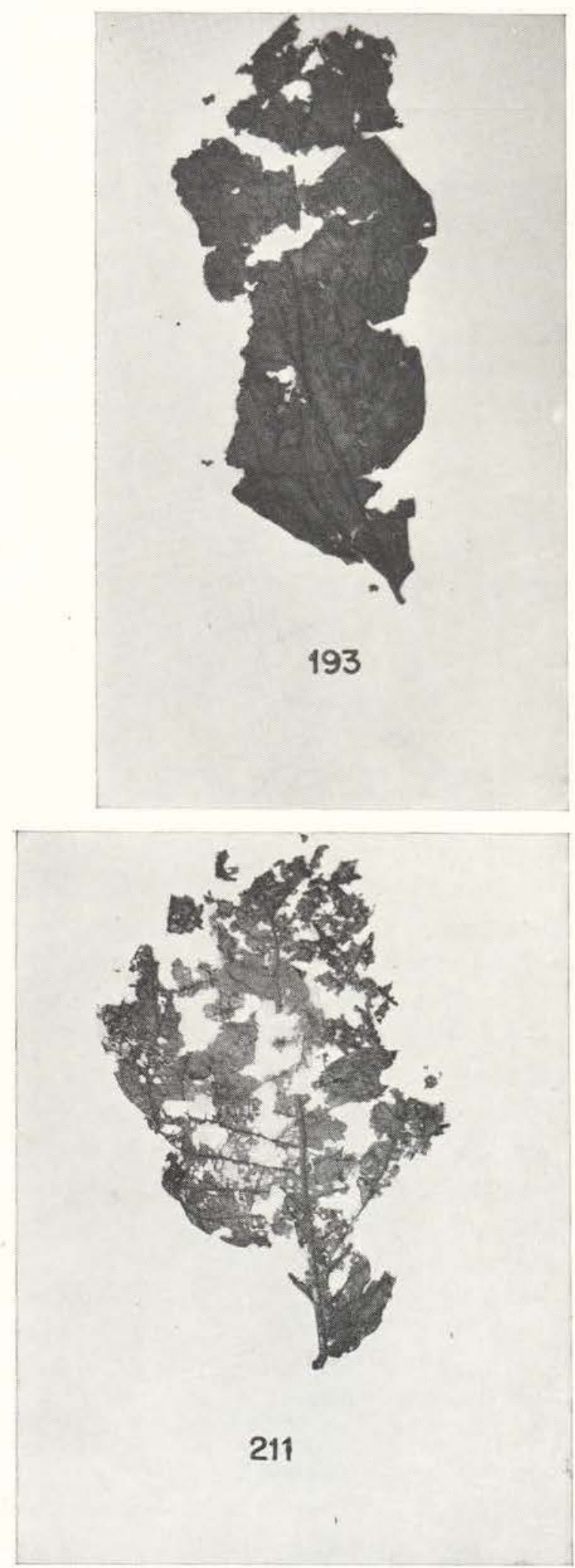

Fig. 7. Nos. 186, 193. Leaves of Caryocar villosum treated with bacteriostat agent and left in "igapó" (blackwater), for one and three months, respectively. N's. 201, 202, 211, Leaves treated similarly but left on oxisol "terra firme" for one and three months respectively. 

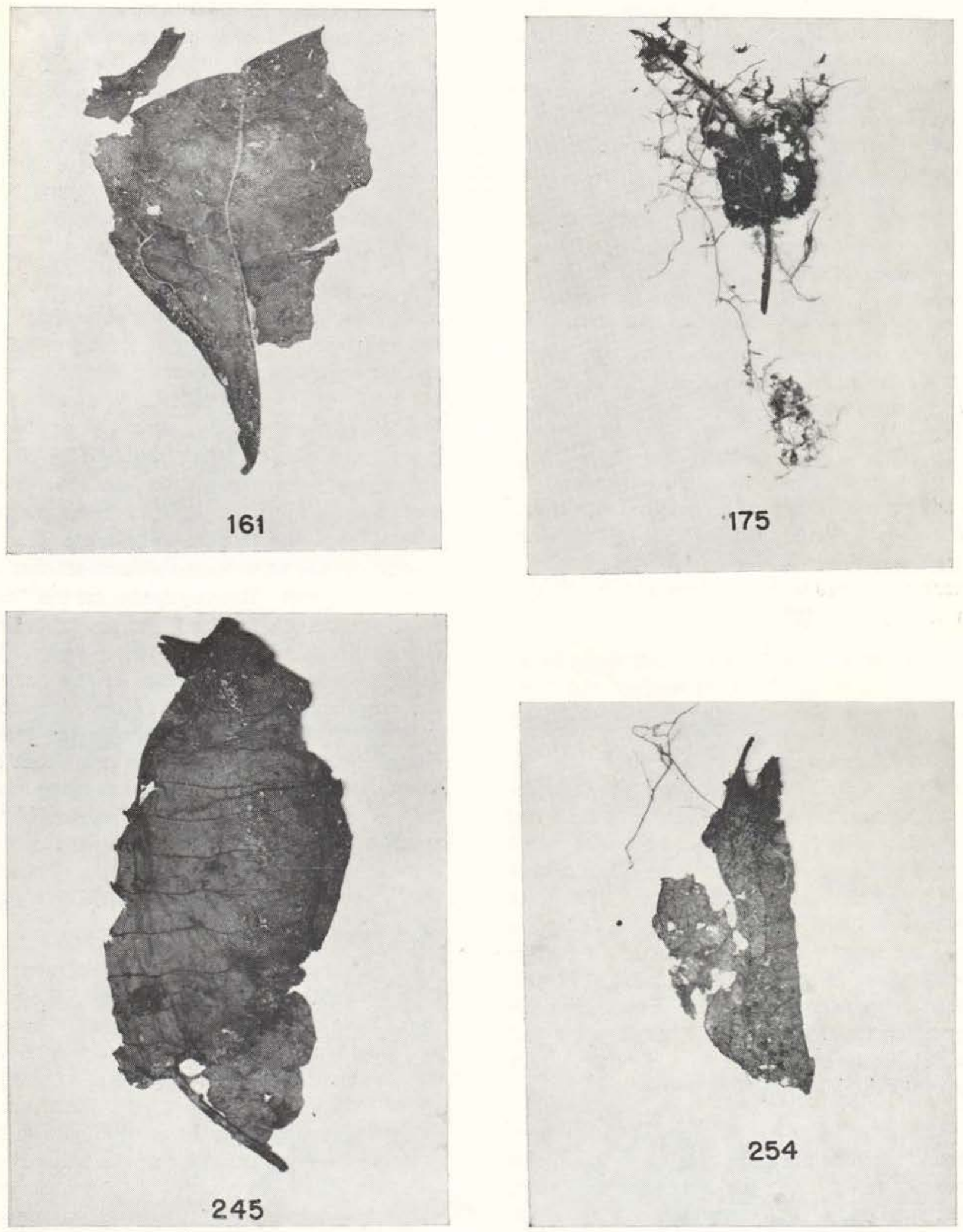

Fig. 8. NoS, 161, 175, Leaves of Caryocar villosum treated with a bacteriostatic agent and left on spodosol "terra firme" for one and three months respectively. Nos. 245, 254 leaves treated with insecticide and left on spodosol "terra firme" for one and three months respectively. 
$31 \mathrm{\mu g} / \mathrm{g}$ from the best "varzea" sites (Table $3)$. The levels of iron on spodosols are comparable to those from earlier studies. Extractable iron on spodosols is comparable to that obtained from earlier studies. Extractable iron is generally sufficient from all areas studied except the "campina" forest on sandstone and the black sand spodosols.

Potassium was generally low from the spodosol areas ranging from 5.5 to $74 \mu \mathrm{g} / \mathrm{g}$. The highest values were from the "campina" forest $(74 \mu \mathrm{g} / \mathrm{g}$ ) and the "varzea" sites (85 $\mathrm{kg} / \mathrm{g}$, Table 3). In 1971, values for $\mathrm{K}$ from this general area ranged from 12 to $320 \mu \mathrm{g} / \mathrm{g}$ (Stark, 1971). In both studies, lowland spodosols which periodically flood had the highest levels of $\mathrm{K}$.

The levels of $\mathrm{Mg}$ were low throughout the siudy with the lowest on lowland spodosols $(2.9 \mu \mathrm{g} / \mathrm{g}$. Table 3), and the highest on "campina" spodosols $(23 \mu \mathrm{g} / \mathrm{g})$. Magnesium from these soil types were reported at 2 to $39 \mu \mathrm{g} / \mathrm{g}$ in 1971 (Stark, 1971).

Manganese was low $(0.3-5.5 \mu \mathrm{g} / \mathrm{g})$ in all the soils studied (Table 3), except the "varzea" sites $(144 \mu \mathrm{g} / \mathrm{g})$.

Nitrogen levels were variable as can be expected for surface soils (Table 3 ). Inundadated sites on the black water "igapó" had only $252 \mu \mathrm{g} / \mathrm{g}$ for nitrogen whereas surface samples from lowland spodosols showed 3164 $\mu \mathrm{gN} / \mathrm{g}$ of soil. The oxisol surface soils did not show significantly higher levels of nitrogen over the spodosols, except for the "terra firme" primary forest with trees to $50 \mathrm{~m}$ height. Oxisols generally had higher levels of nitrogen at $20-25 \mathrm{~cm}$ depth, but most sites had acceptable levels of nitrogen by temperate zone standards.

Because of heavy leaching and the high solubility of sodium salts, this element usually does not tell a great deal about tropical soils. The inundated "igapó" site had $7 \mu \mathrm{g} / \mathrm{g}$ while the inundated varzea soils had $28-31 \mu \mathrm{gNa} / \mathrm{g}$ of soil, and the dry site (not recently flooded) "varzea" sites had $37 \mu \mathrm{g} / \mathrm{g}$ for this element (Table 3). Campina Creek mud had the highest
$\mathrm{Na}(41.3 \mu \mathrm{g} / \mathrm{g})$, except for lowland spodosol sites $(62 \mu \mathrm{g} / \mathrm{g})$. These data suggest that some of the inundated sites are collecting or concentrating $\mathrm{Na}$ while others are losing this element. The levels of $\mathrm{Na}$ found here are comparable to those reported earlier (Stark, 1971).

Zinc was low (0.5 to $1.1 \mu \mathrm{g} / \mathrm{g}$, Table 3) on nearly all soils except the "varzea" (2.3 $\mu \mathrm{g} / \mathrm{g}$ ).

If the surface soils are arranged in the order of total extractable cations from lowest to highest (Table 4), the spodosols (w'th the exception of one agricultural oxisol) all fall in the lower total extractable cation range $(44.8-130.6 \mu \mathrm{g} / \mathrm{g}$. These are exceptionally low levels of extractable cations. A coniferous forest soil will range from $2975 \mu \mathrm{g} / \mathrm{g}$ of extractable cations in the surface soil. Where tree height data are available, the average height tends to increase with the higher levels of extractable cations, except for the "campina" sites. The vegetation on the "campina" sites is low $(8-10 \mathrm{~m})$, and the extractable cations are also low $(80.2-130.6 \mu \mathrm{g} / \mathrm{g})$. The depth of undecomposed litter in the "campina" is generally low (under $2 \mathrm{~cm}$ ), indicating possibly lower production and greater dependence on the soil nutrients, or less direct nutrient cycling from organic litter to living roots. This is consistent with the dry nature of the campina. The highest total extractable cations from surface soil come from the "varzea" which was not flooded in August $(2290.9 \mu \mathrm{g} / \mathrm{g}$, Table 3).

The total extractable cation content of the subsurface soils is generally low (35.3-128.5 $\mu \mathrm{g} / \mathrm{g}$. Table 3). Where tree height is known, the height correlates more closely with the total extractable cations from the subsurface soil than from the surface soil. The "campina" subsoils appear to be higher in total extractable cations than many of the other sites, including the "varzea", but average tree height is extremely low (under $10 \mathrm{~m}$ ) suggesting that some other factor is limiting to growth, possibly the anions $\mathrm{NO}_{2}^{-}$or $\mathrm{PO}_{4}^{-}$. Nitrate is low for soil 2B on sandstone (392-630 $\mu \mathrm{g} / \mathrm{g}$, Table 3). Organic litter and tree height 

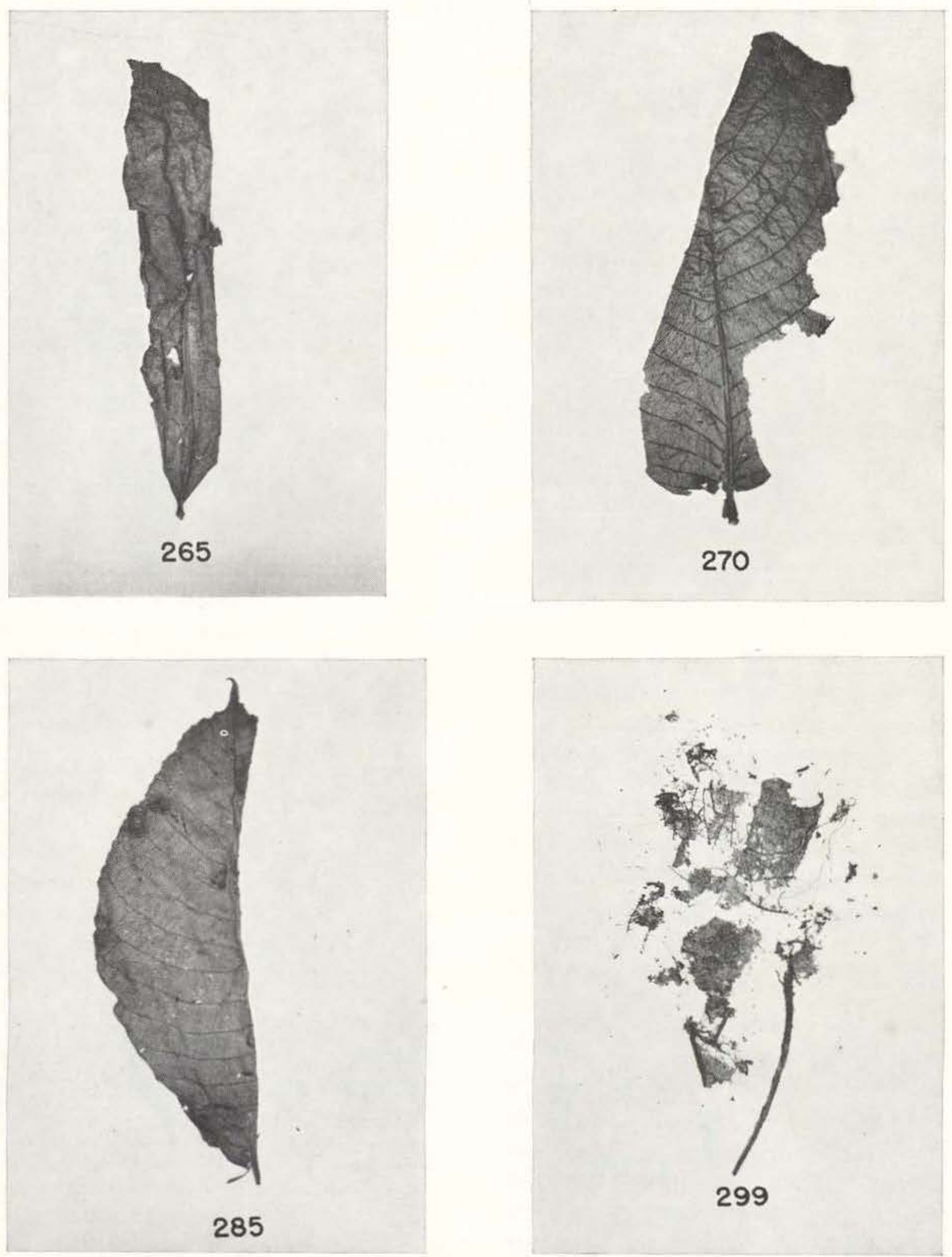

Fig. 9. Nos. 265, 270. Leaves of Caryocar villosum treated with insecticide and left in the black water of the "igapó" for one and two months respectively. Nos. 285, 299 leaves treated similarly, but exposed to oxisol "terra firme" for one and four months respectively. 

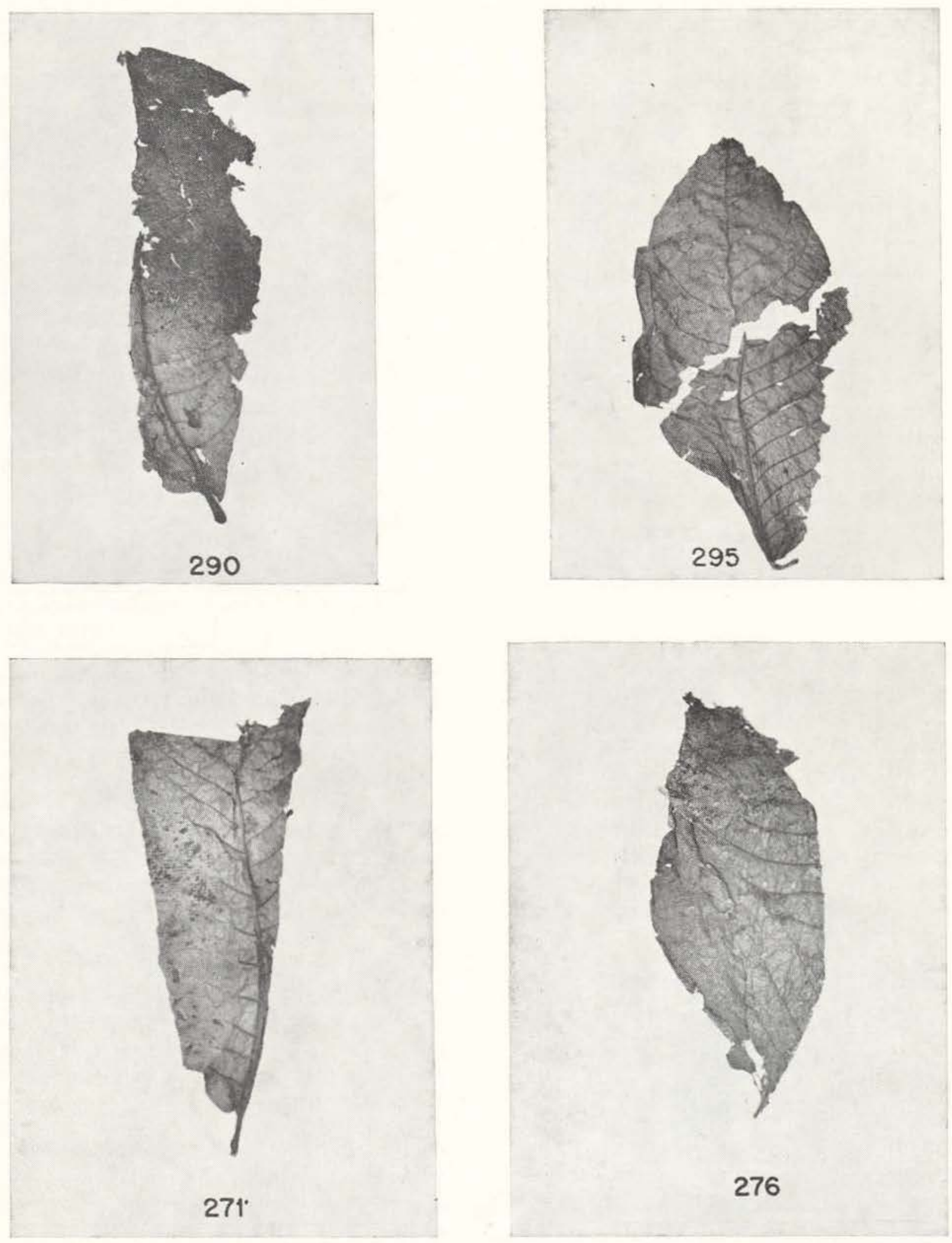

Fig. 10. Nos. 290, 295, Leaves of Caryocar villosum treated with insecticide and placed on oxisol "terra firme" for two and three months respectively. Nos. 271, 276. Leaves treated similarly and left in black water "igapó" for three and four months. 
do not appear to be closely related from these limited data, but more information is definitely needed. For surface soils, the deeper litter tends to be on the poorest soils suggesting a strong dependence on litter. These soils have relatively small forests of $20-30 \mathrm{~m}$ high.

The $\mathrm{pH}$ of surface spodosols averaged 3.65 with 3.98 at $20-25 \mathrm{~cm}$ while the $\mathrm{pH}$ of the "igapó" was 5.45 and 5.35 respectively, and the oxisol sites were 3.84 and 4.28 respectively. The "varzea" pH was 6.58. Soils with earth worms (3.8) were generally in the middle range of extractable cations for the surface and high in extractable cations in the subsoil.

Although this study was not able to sample adequately to fully describe the relations of vegetation to soils and nutrient cycling, the data do indicate some interesting trends. Future studies should include tree height, biomass per hectare, extractable cations, anions, organic litter depth, root mat (depth, and location), and studies of direct and indirect nutrient cycling to fully describe nutrient cycling differences from spodosols and oxisols.

The spodosol terra firme litter appears to be decomposed mainly by fungi (possibly mycorrhizal fungi) and litter animals. This litter also requires a softening period before rapid decay begins. Once the leaves are properly softened, decay is rapid and complete within a month or so. Ants are extremely important decomposers on spodosols.

The richest soils are the "varzea" soils as is well known. There is some relationship between tree height and fertility, but litter depth complicates this relationship.

Caryocar leaves changed in elemental content and percent ash as it decays tending to increase in concentration with time. These leaves are rich in N, P, and $\mathrm{Ca}$. "Varzea" litter is one of the richest types of natural litter types in Amazonia, except in nitrogen. The "Campina" litter is the poorest of forest litters in nutrient content.

\section{CONCLUSIONS}

This brief study cannot hope to have amassed enough data to explain all of the differences in nutrient cycling on black and white water soils. It has been shown that a factor of prime importance is the rate of decomposition and the dominant decomposer groups and their waste products. Studies on the nature of the leaching solution which falls through the forest canopy and contacts the litter on the forest floor were cancelled because of time. Such studies should be continued to fully explain nutrient cycling since it is probably the $\mathrm{pH}$ and chemistry of the leaves and their microenvironments which finally determines which organisms will dominate the decomposition of litter, and in what sequence. Nutrient cycling appears to be strongly related to type and rate of decomposition, and less to soil types, although white water depends on a clay to provide the sediment load. Decomposition occurs in an acid, anaerobic environment which after a time may stagnate further decay. The decay end' products are particulate organics which give the water its color and these can form under water or either oxisols or spodosols if the aeration, $\mathrm{pH}$ and currents are suitable. The $\mathrm{pH}$ of the water coming from the land may also be important to determining the dominant decomposers. The build-up of cations in this litter suggests selective decomposition by bacteria.

Oxisol terrestrial sites appear to be dominated by litter animals which require a period of softening of the leaves by moisture and bacteria before they become abundant. Mycorrhizal fungi and certainly free-living fungi are also important decomposers on oxisols. The nutrient loss pattern suggests decomposers that "eat" chunks of leaf rather than selective decay of one fraction of the leaf. This "eating" reduces all elements proportionately. 
Table 1. Average weight loss as percent of original dry weight for Caryocar villosum leaves under different treatments overtime, Brazil blackwater and whitewater streams and spodosol and oxisol terra firme sites.

\begin{tabular}{|c|c|c|c|c|c|c|c|}
\hline $\begin{array}{l}\text { Site and } \\
\text { Site and } \\
\text { Treatment }\end{array}$ & $\begin{array}{l}\text { Packet } \\
\text { Number }\end{array}$ & $\begin{array}{c}\text { Time } \\
\text { Exposed } \\
\text { Months }\end{array}$ & $\begin{array}{l}\text { Average Weight } \\
\text { Loss \% }\end{array}$ & $\begin{array}{c}\text { Average } \\
\% \\
\text { Cellulose }\end{array}$ & Roots & $\begin{array}{l}\text { Av. No. } \\
\text { Litter } \\
\text { Animais }\end{array}$ & Fungi \\
\hline \multicolumn{8}{|l|}{ CONTROLS } \\
\hline Blackwater $\mathrm{Tf}^{1}$ & $\begin{array}{l}1-5 \\
6-20\end{array}$ & $\begin{array}{l}1 \\
1\end{array}$ & $\begin{array}{r}32.41 \\
100.00 \text { (ants) }\end{array}$ & 17.75 & & 22 & Light \\
\hline \multirow{4}{*}{ Blackwater Ig.! } & $21-25$ & 1 & 35.23 & & None & 2 & V. light \\
\hline & $26-30$ & 2 & 50.67 & 18.14 & None & 14 & V. light \\
\hline & $31-35$ & 3 & 52.60 & $\begin{array}{l}22.60 \\
17.23\end{array}$ & None & $\begin{array}{l}2 \text { midge } \\
\text { larvae }\end{array}$ & V. light \\
\hline & $36-40$ & 4 & 53.40 & & None & 9 & V. light \\
\hline \multirow[t]{3}{*}{ Whitewater $\mathrm{Tf}$} & $41-45$ & 1 & 52.84 & 18.16 & Light & 10 & Light \\
\hline & $46-50$ & 2 & 83.99 & & & & \\
\hline & $51-60$ & 3 & 100.00 & & & & \\
\hline Whitewater varz' & $56-80$ & 1 & (stolen) & & & & \\
\hline FUNGICIDE & & & & & & & \\
\hline Blackwater Tf & $81-100$ & 1 & 100.00 (ants) & & & & \\
\hline \multirow[t]{3}{*}{ Blackwater Ig. } & $101-105$ & 1 & 34.04 & & None & 3 & V. light \\
\hline & $106-110$ & 2 & 39.99 & & None & 13 (midge) & None \\
\hline & $111-115$ & 3 & 44.66 & & None & 7 (midge) & V. light \\
\hline & $116-120$ & 4 & 45.80 & & None & 5 (midge) & V. light \\
\hline \multirow[t]{4}{*}{ Whitewater Tf } & $121-125$ & 1 & 19.79 & & $\begin{array}{l}\text { None to } \\
\text { medium }\end{array}$ & 3 & V. light \\
\hline & $126-130$ & 2 & 33.11 & & Medium & 3 & Medium \\
\hline & $131-135$ & 3 & 78.52 & & Medium & Incomplete & V. heavy \\
\hline & $136-140$ & 4 & 100.00 & & & & \\
\hline Whitewater varz & $140-160$ & 1 & (stolen) & & & & \\
\hline BACTERIOSTAT & & & & & & & \\
\hline \multirow[t]{2}{*}{ Blackwater Tf } & $161-165$ & 1 & 49.87 & & Medium & 18 & Light \\
\hline & $166-180$ & 2 & 100.00 (ants) & & Heavy & & \\
\hline \multirow[t]{4}{*}{ Blackwater Ig. } & $181-185$ & 1 & 31.86 & & None & 1 & V. light \\
\hline & $186-190$ & 2 & 45.98 & & None & 21 & V. light \\
\hline & 191-195 & 3 & 54.07 & & None & 10 (midge) & V. light \\
\hline & $196-200$ & 4 & 57.70 & & None & 8 (midge) & V. light \\
\hline \multirow[t]{4}{*}{ Whitewater Tf } & $201-205$ & 1 & 29.08 & & None & 12 & Light \\
\hline & $206-210$ & 2 & 68.86 & & Light & 4 & Light \\
\hline & 211-215 & 3 & 51.22 & & Medium & 4 & Light \\
\hline & $216-220$ & 4 & 100.00 & & & & \\
\hline Whitewater varz & $220-240$ & 1 & (stolen) & & & & \\
\hline INSECTICIDE & & & & & & & \\
\hline \multirow{2}{*}{ Blackwater Tf } & $241-245$ & 1 & 31.01 & & Light & 6 & Medium \\
\hline & $246-250$ & 2 & 32.50 & & Medium & 0 & Medium \\
\hline \multirow[t]{2}{*}{$+\infty$} & $251-255$ & 3 & 48.83 & & Light & 6 & Medium \\
\hline & $256-260$ & 4 & 75.64 & & Light & Incomplete & V. light \\
\hline \multirow{4}{*}{ Blackwater Ig. } & 261-265 & 1 & 24.22 & & None & 0 & \\
\hline & $266-270$ & 2 & 42.22 & & None & 0 & V. light \\
\hline & $271-275$ & 3 & 45.74 & & None & 2 (midge) & V. light \\
\hline & $276-280$ & 4 & 56.92 & & None & 4 (midge) & V. light \\
\hline \multirow[t]{4}{*}{ Whitewater Tf } & $281-285$ & 1 & 21.19 & & None & 0 & V. light \\
\hline & $286-290$ & 2 & 37.02 & & Light & 0 & Light \\
\hline & 291-295 & 3 & 45.71 & & Medium & 14 & Light \\
\hline & $296-300$ & 4 & 53.20 & & Medium & 10 & V. heavy \\
\hline Whitewater Varz & $301-320$ & 1 & (stolen) & & & & \\
\hline
\end{tabular}

(1) - Blackwater Tf $=$ spodiosol, not flooded, whitewater Tf $=$ oxisol, not flooded.

(2) Blackwater Ig. $=$ spodosol, flooded, whitewater varz. = oxiscl, periodic flooding. 


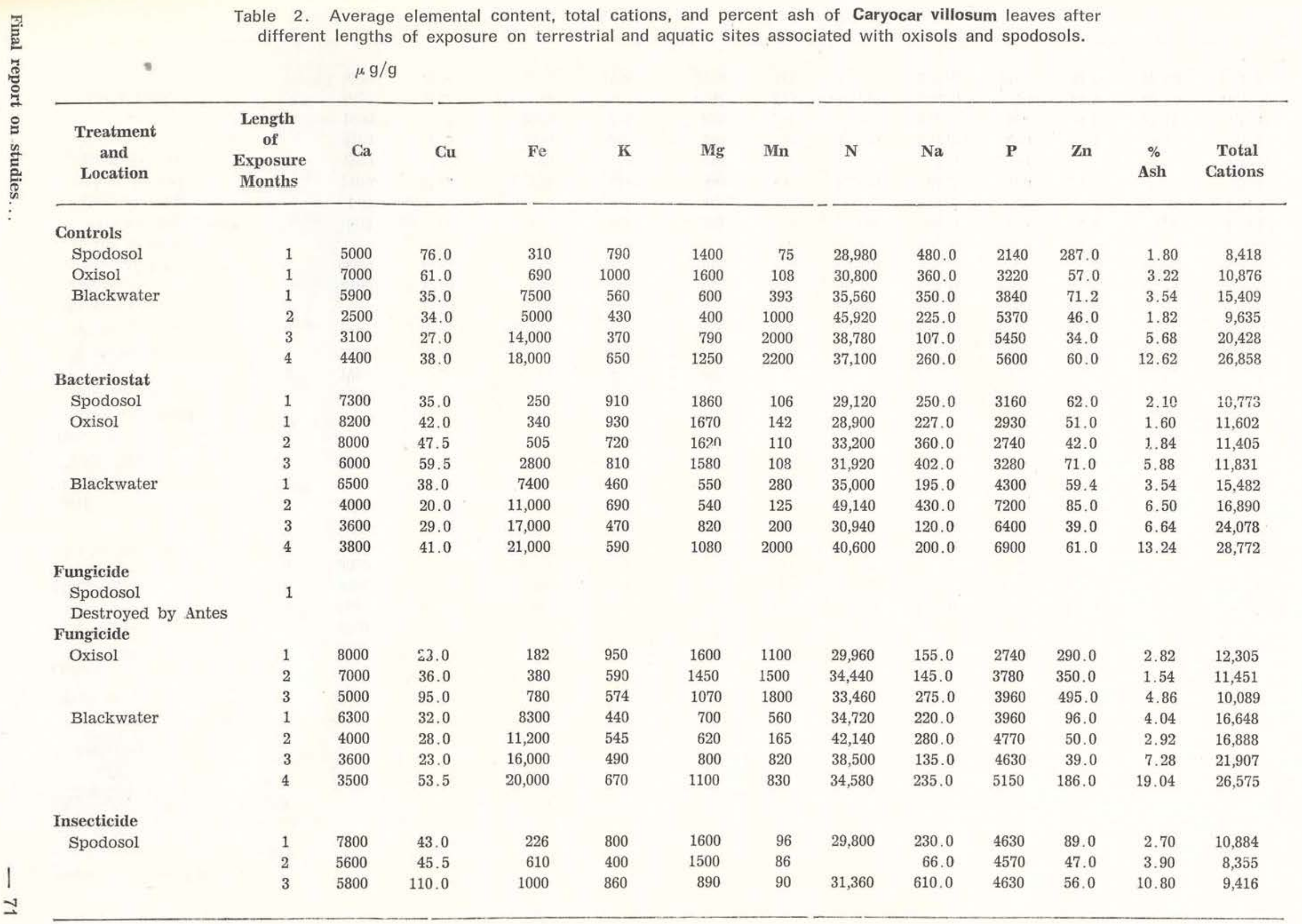


$\mu \mathrm{g} / \mathrm{g}$

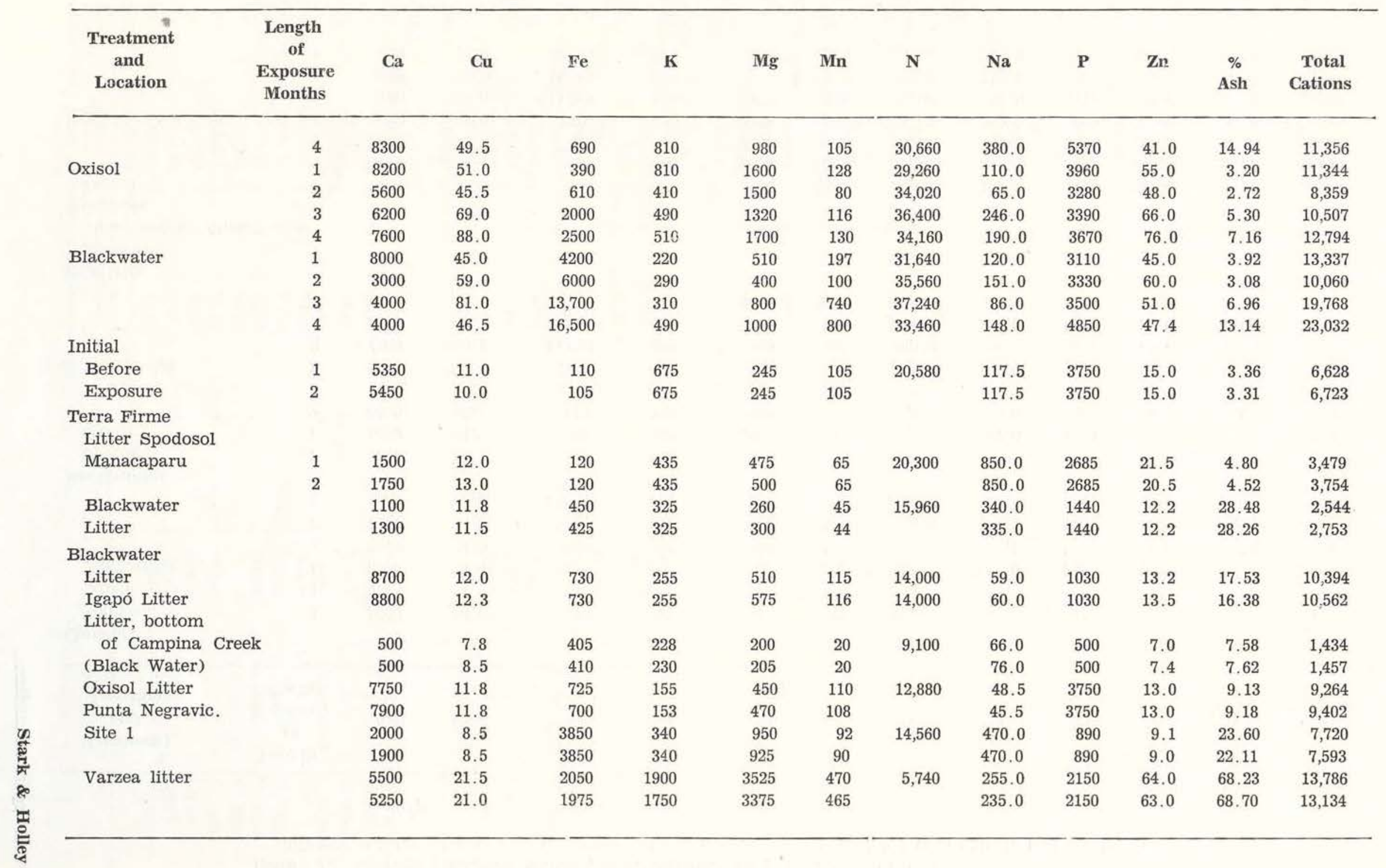




\begin{tabular}{|c|c|c|c|c|c|c|c|c|c|c|}
\hline Site & $\begin{array}{l}\text { Depth } \\
\text { cm }\end{array}$ & $\mathrm{Ca}$ & $\mathrm{Cu}$ & $\mathrm{Fe}$ & $\mathbf{K}$ & Mg & Mn & $\mathbf{N}$ & $\mathrm{Na}$ & $\mathrm{Zn}$ \\
\hline \multicolumn{11}{|l|}{ Blackwater } \\
\hline Igapó & $0-5$ & 26 & 0.9 & 3.8 & 10.0 & 3.8 & 0.7 & 252 & 7.0 & 1.0 \\
\hline \multirow[t]{3}{*}{ (inundated) } & & 26 & 0.9 & 3.8 & 10.0 & 3.9 & 0.7 & & 7.0 & 1.0 \\
\hline & $20-25$ & 15 & 1.0 & 2.5 & 8.5 & 3.2 & 0.4 & 210 & 7.0 & 0.8 \\
\hline & & 15 & 1.0 & 2.5 & 9.0 & 3.1 & 0.4 & & 8.4 & 0.8 \\
\hline \multicolumn{11}{|l|}{ Lowland } \\
\hline Spodosol & $0-5$ & 12.5 & 1.5 & 22.5 & 32.5 & 9.2 & 0.8 & 3164 & 26.0 & 0.7 \\
\hline trees & & 11.0 & 1.5 & 22.5 & 31.0 & 9.2 & 0.8 & & 25.2 & 0.8 \\
\hline \multirow[t]{2}{*}{$25 \mathrm{~m}$} & $20-25$ & 11.5 & 1.5 & 5.5 & 40.0 & 5.0 & 0.2 & 1372 & 62.0 & 0.5 \\
\hline & & 11.5 & 1.5 & 5.8 & 41,0 & 5.0 & 0.2 & & 62.0 & 0.5 \\
\hline \multicolumn{11}{|l|}{ Lowland } \\
\hline Spodosol & $0-5$ & 10.0 & 1.5 & 12.8 & 23.5 & 6.7 & 0.5 & 2785 & 18.5 & 0.7 \\
\hline trees & & 10.0 & 1.4 & 12.8 & 23.5 & 6.7 & 0.5 & & 17.0 & 0.6 \\
\hline \multirow{2}{*}{$30 \mathrm{~m}$} & $20-25$ & 10.0 & 1.3 & 6.3 & 15.0 & 3.0 & 0.3 & 980 & 13.2 & 0.5 \\
\hline & & 10.0 & 1.3 & 6.5 & 15.0 & 2.9 & 0.3 & & 13.5 & 0.5 \\
\hline \multicolumn{11}{|l|}{ Campina-like } \\
\hline soil on & $0-5$ & 25.0 & 2.5 & 1.1 & 30.0 & 12.5 & 0.6 & 630 & 13.0 & 1.0 \\
\hline $\begin{array}{l}\text { sand stone } \\
\text { trees } 10 \mathrm{~m}\end{array}$ & & 20.0 & 2.3 & 1.1 & 25.0 & 12.0 & 0.5 & & 13.0 & 0.8 \\
\hline \multirow{2}{*}{ (Stream areas) } & $20-25$ & 10.0 & 2.3 & 0.8 & 10.0 & 4.3 & 0.1 & 392 & 11.0 & 0.8 \\
\hline & & 10.0 & 2.3 & 0.9 & 10.0 & 4.5 & 0.1 & & 11.5 & 0.8 \\
\hline \multicolumn{11}{|l|}{ Terra firme } \\
\hline \multirow{2}{*}{$\begin{array}{l}\text { Spodosol } \\
\text { trees }\end{array}$} & $0-5$ & 10.0 & 2.5 & 6.5 & 14.0 & 5.2 & 0.2 & 1316 & 14.0 & 0.8 \\
\hline & & 10.0 & 2.5 & 6.5 & 14.0 & 5.2 & 0.2 & & 14.0 & 0.8 \\
\hline \multirow[t]{2}{*}{$30 \mathrm{~m}$} & $20-25$ & 10.0 & 2.1 & 6.0 & 5.5 & 3.0 & 0.2 & 630 & 11.0 & 0.7 \\
\hline & & 10.0 & 2.1 & 5.6 & 6.0 & 3.2 & 0.2 & & 11.4 & 0.7 \\
\hline \multicolumn{11}{|l|}{ Dark, deep } \\
\hline black sand & $0-5$ & 10.0 & 1.5 & 1.8 & 16.0 & 5.0 & 0.3 & 518 & 10.6 & 0.8 \\
\hline Spodosol & & 10.5 & 1.5 & 1.8 & 21.0 & 6.0 & 0.3 & & 10.0 & 0.8 \\
\hline trees & $20-25$ & 10.0 & 1.5 & 2.0 & 10.0 & 3.8 & 0.1 & 364 & 8.0 & 0.7 \\
\hline $20 \mathrm{~m}$ & & 9.5 & 1.4 & 2.0 & 9.0 & 3.2 & 0.1 & & 8.5 & 0.7 \\
\hline \multicolumn{11}{|l|}{ Manacaparu } \\
\hline \multirow[t]{4}{*}{ Spodosol } & $0-5$ & 10.0 & 1.3 & 6.3 & 12.0 & 4.5 & 0.4 & 644 & 10.0 & 0.7 \\
\hline & & 9.5 & 1.2 & 6.3 & 12.0 & 4.5 & 0.4 & & 10.0 & 0.6 \\
\hline & $20-25$ & 11.0 & 1.3 & 4.8 & 17.0 & 5.5 & 0.3 & 728 & 23.5 & 0.5 \\
\hline & & 11.0 & 1.3 & 4.8 & 17.0 & 5.6 & 0.3 & & 24.5 & 0.5 \\
\hline
\end{tabular}




\begin{tabular}{|c|c|c|c|c|c|c|c|c|c|c|}
\hline Site & $\begin{array}{l}\text { Depth } \\
\text { cm }\end{array}$ & $\mathrm{Ca}$ & $\mathbf{C u}$ & $\mathrm{Fe}$ & $\mathbf{K}$ & Mg & Mn & $\mathbf{N}$ & $\mathrm{Na}$ & $\mathbf{Z n}$ \\
\hline \multicolumn{11}{|l|}{ Blackwater } \\
\hline \multirow[t]{4}{*}{ Terra firme } & $0-5$ & 15.0 & 0.9 & 11.0 & 12.5 & 5.5 & 0.5 & 700 & 14.0 & 1.0 \\
\hline & & 9.5 & 1.2 & 6.3 & 12.0 & 4.5 & 0.4 & & 10.0 & 0.6 \\
\hline & $20-25$ & 11.0 & 1.3 & 4.8 & 17.0 & 5.5 & 0.3 & 728 & 23.5 & 0.5 \\
\hline & & 11.0 & 1.3 & 4.8 & 17.0 & 5.6 & 0.3 & & 24.5 & 0.5 \\
\hline \multicolumn{11}{|l|}{ Blackwater } \\
\hline Terra firme & $0-5$ & 15.0 & 0.9 & 11.0 & 12.5 & 5.5 & 0.5 & 700 & 14.0 & 1.0 \\
\hline \multirow[t]{3}{*}{ Spodosol } & & 15.0 & 0.9 & 12.5 & 13.0 & 5.0 & 0.5 & & 15.5 & 0.9 \\
\hline & $20-25$ & 19.0 & 0.8 & 6.3 & 11.0 & 5.0 & 0.5 & 742 & 11.0 & 0.6 \\
\hline & & 19.0 & 0.9 & 5.8 & 11.0 & 5.3 & 0.5 & & 11.0 & 0.6 \\
\hline \multicolumn{11}{|l|}{ Low forest } \\
\hline \multirow{2}{*}{$\begin{array}{r}\text { Spodosol } \\
\text { trees }\end{array}$} & $0-5$ & 10.0 & 1.4 & 15.0 & 27.5 & 7.0 & 0.3 & 2660 & 22.5 & 0.6 \\
\hline & & 11.0 & 1.4 & 15.0 & 27.5 & 7.3 & 0.3 & & 22.5 & 0.6 \\
\hline \multirow[t]{2}{*}{$35 \mathrm{~m}$} & $20-25$ & 10.0 & 1.1 & 6.8 & 20.0 & 3.0 & 0.1 & 1190 & 19.0 & 0.6 \\
\hline & & 10.0 & 1.1 & 6.8 & 20.0 & 3.2 & 0.1 & & 19.0 & 0.6 \\
\hline \multicolumn{11}{|l|}{ Campina-like } \\
\hline \multirow{4}{*}{$\begin{array}{l}\text { forest } \\
\text { Spodosol }\end{array}$} & $0-5$ & 17.0 & 1.3 & 2,5 & 70.0 & 22.0 & 0.6 & & 13.5 & 0.9 \\
\hline & & 17.0 & 1.3 & 2.5 & 74.0 & 23.0 & 0.6 & & 14.0 & 0.9 \\
\hline & $20-25$ & 25.0 & 1.1 & 10.0 & 41.0 & 14.5 & 2.2 & & 34.0 & 0.7 \\
\hline & & 25.0 & 1.1 & 10.0 & 41.0 & 14.5 & 2.2 & & 34.0 & 0.6 \\
\hline \multicolumn{11}{|l|}{ Agricultural } \\
\hline Oxisol & $0-5$ & 15.0 & 2.5 & 18.0 & 27.0 & 10.9 & 1.0 & 2016 & 14.0 & 0.8 \\
\hline \multirow{3}{*}{ AGL } & & 15.0 & 2.5 & 18.0 & 26.5 & 10.6 & 1.0 & & 14.0 & 0.9 \\
\hline & $20-25$ & 15.0 & 2.2 & 9.0 & 22.5 & 6.5 & 1.5 & 1036 & 12.5 & 0.8 \\
\hline & & 15,0 & 2.3 & 9.0 & 21.5 & 6.5 & 1.5 & & 12.0 & 0.7 \\
\hline \multicolumn{11}{|l|}{ Terra firme } \\
\hline \multirow{4}{*}{$\begin{array}{l}\text { Primary forest } \\
\text { trees to } \\
50 \mathrm{~m}\end{array}$} & $0-5$ & 20.0 & 1.3 & 19.8 & 42.5 & 17.5 & 1.0 & 3556 & 27.5 & 0.7 \\
\hline & & 20.0 & 1.3 & 19.8 & 42.5 & 17.5 & 1.0 & & 27.5 & 0.7 \\
\hline & $20-25$ & 50.0 & 1.5 & 5.0 & 20.0 & 21.0 & 1.4 & 1610 & 19.6 & 0.5 \\
\hline & & 50.0 & 1.4 & 5.0 & 20.0 & 22.0 & 1.5 & & 19.2 & 0.5 \\
\hline \multicolumn{11}{|l|}{ Punta Negra } \\
\hline \multirow[t]{2}{*}{ Spodosol } & $0-5$ & 22.5 & 1.2 & 14.5 & 53.5 & 15.2 & 1.0 & 3975 & 23.5 & 0.7 \\
\hline & & 20.0 & 1.2 & 14.8 & 53.0 & 15.2 & 0.9 & & 22.5 & 0.7 \\
\hline \multirow[t]{2}{*}{-} & $20-25$ & 10.5 & 1.4 & 4.8 & 20.0 & 6.8 & 0.3 & 1624 & 18.0 & 0.5 \\
\hline & & 10.0 & 1.3 & 5.0 & 20.0 & 6.6 & 0.3 & & 18.0 & 0.5 \\
\hline
\end{tabular}




\begin{tabular}{|c|c|c|c|c|c|c|c|c|c|c|}
\hline Table 3. s (continu & & & & & & & & & & \\
\hline Site & $\begin{array}{l}\text { Depth } \\
\text { cm }\end{array}$ & $\mathrm{Ca}$ & $\mathrm{Cu}$ & $\mathrm{Fe}$ & $\mathbf{K}$ & Mg & Mn & $\mathbf{N}$ & $\mathrm{Na}$ & $\mathbf{Z n}$ \\
\hline \multicolumn{11}{|l|}{ Terra firme } \\
\hline Spodosol & $0-5$ & 17.5 & 1.9 & 25.0 & 39.0 & 13.0 & 1.0 & 2800 & 29.3 & 0.7 \\
\hline \multirow{3}{*}{$\begin{array}{l}\text { Small earth- } \\
\text { worms, trees } \\
30 \mathrm{~m}\end{array}$} & & 17.5 & 1.9 & 25.0 & 39.0 & 13.0 & 1.0 & & 28.0 & 0.7 \\
\hline & $20-25$ & 10.0 & 1.5 & 7.0 & 28.0 & 4.2 & 0.4 & 1400 & 25.0 & 0.6 \\
\hline & & 10.0 & 1.5 & 7.0 & 28.0 & 4.0 & 0.4 & & 25.0 & 0.5 \\
\hline \multirow[t]{4}{*}{ Oxisol } & $0-5$ & 25.0 & 1.1 & 10.0 & 41.0 & 14.5 & 2.2 & 3010 & 34.0 & 0.7 \\
\hline & & 25.0 & 1.1 & 10.0 & 41.0 & 14.5 & 2.2 & & 34.0 & 0.6 \\
\hline & $20-25$ & 13.0 & 1.5 & 3.8 & 15.0 & 6.2 & 0.3 & 1778 & 11.7 & 0.5 \\
\hline & & 13.0 & 1.5 & 3.8 & 15.0 & 6.2 & 0.3 & & 13.0 & 0.5 \\
\hline \multicolumn{11}{|l|}{ Oxisol } \\
\hline \multirow[t]{4}{*}{ NAT } & $0-5$ & 26.0 & 2.0 & 24.5 & 47.5 & 20.5 & 2.0 & 3220 & 12.0 & 1.0 \\
\hline & & 25.0 & 2.0 & 24.8 & 47.5 & 20.5 & 2.0 & & 12.0 & 1.0 \\
\hline & $20-25$ & 14.0 & 1.7 & 5.5 & 26.0 & 6.0 & 1.7 & 1316 & 10.5 & 0.6 \\
\hline & & 13.0 & 1.7 & 5.3 & 26.0 & 5.6 & 1.7 & & 10.0 & 0.6 \\
\hline \multicolumn{11}{|l|}{ Innundated } \\
\hline \multirow[t]{2}{*}{ muck } & $0-5$ & 1350.0 & 1.9 & 7.5 & 80.0 & 170.0 & 143.8 & 1078 & 31.0 & 2.1 \\
\hline & & 1350.0 & 1.9 & 7.5 & 80.0 & 175.0 & 142.5 & & 28.5 & 2.3 \\
\hline \multicolumn{11}{|l|}{ Varzea bank } \\
\hline \multirow{2}{*}{$\begin{array}{l}\text { sediments, } \\
\text { not recently }\end{array}$} & $0-5$ & 1800.0 & 1.4 & 2.5 & 85.0 & 255.0 & 107.5 & 532 & 37.5 & 1.1 \\
\hline & \multicolumn{9}{|c|}{ flooded, but grazed. } & 1.1 \\
\hline \multicolumn{11}{|l|}{ Campina Creek } \\
\hline \multirow[t]{2}{*}{ mud } & $0-5$ & 47.5 & 1.0 & 2.0 & 47.5 & 18.5 & 1.6 & 2450 & 400 & 0.8 \\
\hline & & 47.5 & 1.0 & 2.0 & 47.5 & 20.0 & 1.5 & & 41.3 & 0.8 \\
\hline \multirow{5}{*}{$\begin{array}{l}\text { Varzea } \\
\text { dry site }\end{array}$} & & & & & & & & & & \\
\hline & $0-5$ & 118.5 & 3.0 & 30.0 & 72.5 & 37.3 & 5.5 & 3360 & 16.5 & 1.4 \\
\hline & & 116.0 & 3.0 & 31.0 & 70.0 & 37.3 & 5.5 & & 16.5 & 1.4 \\
\hline & $20-25$ & 15.0 & 2.4 & 5.0 & 25.0 & 8.9 & 1.8 & 1050 & 13.1 & 0.9 \\
\hline & & 15.0 & 2.5 & 5.2 & 25.0 & 8.9 & 1.8 & & 12.0 & 0.8 \\
\hline
\end{tabular}


Table 4. Average total extractable suil cations ( $\mathrm{Ca}, \mathrm{Cu}, \mathrm{Fe}, \mathrm{K}, \mathrm{Mg}, \mathrm{Mn} . \mathrm{Na}, \mathrm{Zn}$ ) from Brazil spodosols and oxisols.

$\begin{array}{clr}\text { Soil No. } & \text { Surface Soils } \mathbf{0 - 5} \mathbf{~ c m} & \text { Av. } \\ & & \\ 9 & \text { Manacaparu Spodosol } & 44.8 \\ 4 & \text { Dark Sand Spodosol } & 48.9 \\ 1 & \text { Terra Firme Spodosol } & 53.2 \\ 10 & \text { Blackwater Igapo' } & 53.3 \\ 11 & \text { Blackwater Terra Firme } & 62.7 \\ 6 & \text { Lowland Spodosol } & 73.4 \\ 12 & \text { Agricultural Oxisol } & 79.6 \\ 2 \mathrm{~b} & \text { Campina on Sandstone } & 80.2 \\ 7 & \text { Lowland Spodosol } & 84.9 \\ 5 & \text { Lowland Spodosol } & 103.9 \\ 8 & \text { Terra Firme Spodosol } & 126.8 \\ 13 & \text { Oxisol } & 128.5 \\ 14 & \text { Punta Negra Spodosol } & 130.2 \\ 3 & \text { Terra Firme Primary For. } & 130.3 \\ 2 \mathrm{a} & \text { Campina Spodosol } & 130.6 \\ 15 & \text { Oxisol Nat } & 135.2 \\ 16 & \text { Campina Creek Mud } & 161.6 \\ 17 & \text { Varzea-Dry Site } & 282.7 \\ 18 & \text { Varzea, inundated } & 1787.0 \\ 19 & \text { Varzea, not flooded } & 2290.9\end{array}$

\section{Subsurface Soils $20-25 \mathrm{~cm}$}

\section{Dark Sand Spodosol}

Terra Firme Spodosol

Blackwater Igapo'

Campina on Sandstone

Lowland Spodosol

Terra Firme Spodosol

Low Forest Spodosol

Punta Negra Spodosol

Manacaparu Spodosol

Oxisol Nat

Varzea - dry site

Agricultural Oxisol

Terra Firme Primary For.

Lowland Spodosol

Campina Spodosol

35.3

38.9

39.3

39.7

49.8

54.2

60.3

62.0

64.5

64.9

71.7

72.4

119.3

126.8

128.5

\section{Resumo}

Estudos realizados próximo a Manaus, Brasil, em cooperação com o INPA, a fim de tentar estabelecer de que maneira o ciclo de nutrientes influencia a formação de "água preta" e "água branca". Medida a taxa de decomposição das folhas de Caryocar villosum sobre solos das ordens spodsol e oxisol, tanto em ambientes aquáticos como terrestres, com as folhas sem tratamento e tratadas com um bactericida, um fungicida ou um inseticida. Mediram-se ainda a quantidade de litter, as populações de animais e o teor de dez elementos

biologicamente importantes no solo e no material vegetal em decomposição. Os resultados mostram diferenças consideráveis nas taxas de decomposição, bem como nos agentes e produtos finais da mesma, indicando estar a formação da "água preta" e da "água branca" intimamente ligada à taxa e tipo de decomposição, aos tipos básicos de solos e vegetação associada. Os sedimentos na água branca constituem exceção.

\section{Literature Cited}

BRINKMAN, W.L.F.

1970 - Natural waters in Amazonia. Amazônia. 11(4): $443-448$.

FitTKaU, E.

1967 - On the ecology of Amazonian rainforest streams. Atas do Simp. sobre a Biota Amazônica, 3(Limnologia):97-108.

GIBBS, R. J.

1967 - Amazon River: environmental factors that control its dissolved and suspended load. Science, 156:1734-1737.

KLINGE, H.

1967 - Podzol Soils: a source of black water rivers in Amazonia. Atas do Simp. sobre a Biota Amazônica, 3(Limnologia) :117-125.

SIOLI, $\mathrm{H}$.

1966 - Soils in the estuary of the Amazon. Humid Tropics Research Scientific Problems of the Humid Tropic Zone Deltas and their implications. Proc. of the Dacca Symposium, UNESCO, $p$. 89-96.

SIOLI, H. ET ALII

1969 - Limnological outlooks on landscape ecology in Latin America. Tropical Eco$\log y, 10(1): 72-82$.

SCHMIDT, G. W.

1970 - Amounts of suspended solids and dissolved substances in the middle reaches of the Amazon over the course of one year. (Aug. 1969-July, 1970). Amazônia, $11(2): 208-223$.

STARK, N.

1971a - Nutrient Cycling. I. Soils. Tropical Ecology, 12(1):24-50.

$1971 \mathrm{~b}-$ Nutrient Cycling. II. Vegetation. Tropical Ecology, 12(2):177-201.

WENT, F. W. \& STARK, N.

1968 - Mycorrhiza. Bio Science, 18(11):10351039.

Williams, W. A. ET ALII

1972 - Environment of evergreen forests on the Lower Rio Negro Brazil. Tropical Ecology, 13(1):65-78. 